ORNL/TM-12499

Dist. Category UC-202

Engineering Technology Division

\title{
TRANSPHASE COOL STORAGE TEST REPORT
}

Therese K. Stovall

Date Published: December 1993

Prepared for the

Electric Power Research Institute

under Interagency Agreement No. DOE ERD-91-1022

Prepared by the

OAK RIDGE NATIONAL LABORATORY

Oak Ridge, Tennessee 37831-6285

managed by

MARTIN MARIETTA ENERGY SYSTEMS, INC.

for the

U.S. DEPARTMENT OF ENERGY

under contract DE-AC05-840R21400

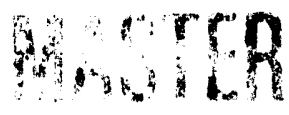


LIST OF FIGURES $\ldots \ldots \ldots \ldots \ldots \ldots \ldots \ldots \ldots \ldots$

LIST OF TABLES $\ldots \ldots \ldots \ldots \ldots \ldots \ldots \ldots \ldots \ldots \ldots \ldots$ vii

ABBREVIATIONS AND SYMBOLS $\ldots \ldots \ldots \ldots \ldots \ldots \ldots \ldots$ ix

ACKNOWLEDGMENTS $\ldots \ldots \ldots \ldots \ldots \ldots \ldots \ldots \ldots \ldots \ldots \ldots$

ABSTRACT $\ldots \ldots \ldots \ldots \ldots \ldots \ldots \ldots \ldots \ldots \ldots$

1. INTRODUCTION $\ldots \ldots \ldots \ldots \ldots \ldots \ldots \ldots \ldots \ldots \ldots \ldots$

2. SYSTEM DESCRIPTION $\ldots \ldots \ldots \ldots \ldots \ldots \ldots \ldots \ldots$

2.1 TRANSPHASE STORAGE SYSTEM ............ 4

2.2 TEST FACILITY $\ldots \ldots \ldots \ldots \ldots \ldots \ldots \ldots \ldots$

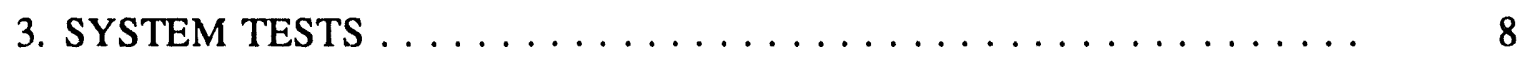

4. ANALYSIS METHODOLOGY .................. 9

4.1 DATA PROCESSING ................. 9

4.2 REFRIGERATION EFFECT $\ldots \ldots \ldots \ldots \ldots \ldots \ldots$

4.3 DISCHARGE ENERGY AVAILABLE ............. 11

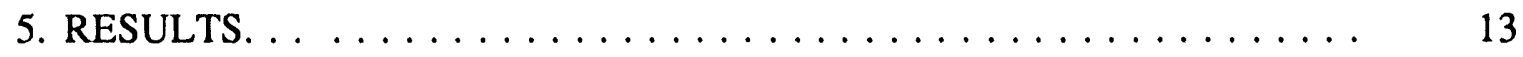

5.1 GENERAL OPERATION $\ldots \ldots \ldots \ldots \ldots \ldots \ldots$

5.2 CHARGING PERFORMANCE $\ldots \ldots \ldots \ldots \ldots \ldots \ldots$

5.3 DISCHARGE PERFORMANCE .............. 25

5.4 STANDBY HEAT GAINS ................. 34

6. CONCLUSIONS AND RECOMMENDATIONS . . . . . . . . . . . 37

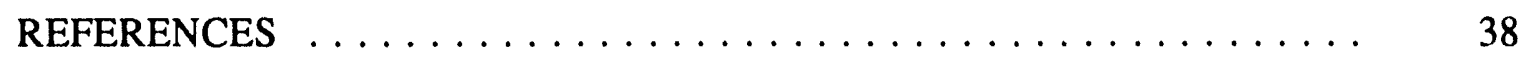

APPENDIX A: ISTF INSTRUMENTATION . . . . . . . . . . . . . 39 


\section{LIST OF FIGURES}

Figure

Page

1 ISTF schematic for Transphase storage system . . . . . . . . . . 5

2 Transphase sto:age tank heat exchanger pressure drop with all nine circuits open for $25 \%$ glycol brine . . . . . . . . . . . . 13

3 Caustic concentration in the Transphase storage tank ........... 15

$4 \mathrm{NaOH} / \mathrm{H}_{2} \mathrm{O}$ phase diagram $\ldots \ldots \ldots \ldots \ldots \ldots \ldots \ldots \ldots$

5 Caustic temperature measured 21 in. below surface during

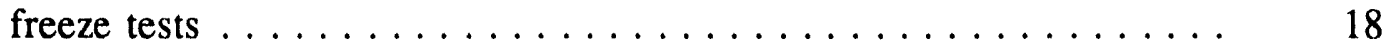

6 Two charge tests starting from fully-melted state $\ldots \ldots \ldots \ldots \ldots \ldots$

7 Temperature profiles for tests 0508 and 0530 differ based

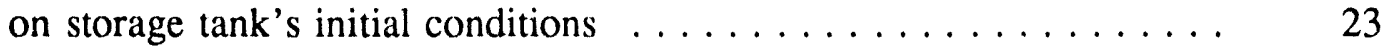

8 Charge test 0606 began with some frozen eutectic in the tank and charged at a rate of -19 ton $\ldots \ldots \ldots \ldots \ldots \ldots$

9 Charging rate varies only slightly during course of nine

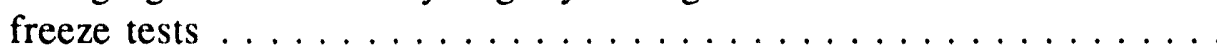

10 Brine inlet and average temperatures for tests with charging

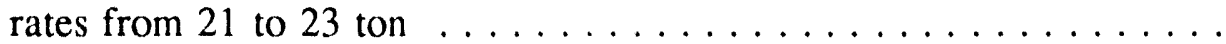

11 Brine temperature at storage tank outlet during

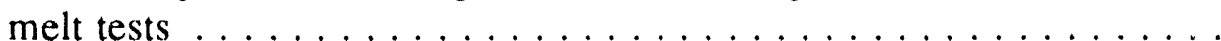

$12 \mathrm{NaOH}$ temperature measured -21 in. below surface during

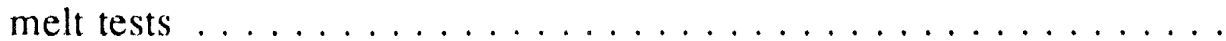

13 Brine flow rates for two different control strategies during

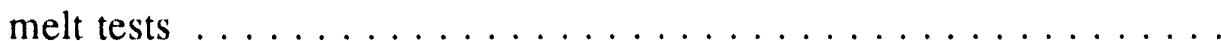

14 Storage tank outlet temperature for two different control strategies during melt tests $\ldots \ldots \ldots \ldots \ldots \ldots \ldots \ldots$

15 Variable discharge rate during melt test 0625

16 Storage tank outlet temperatures for controlled tank inlet temperature of $60^{\circ} \mathrm{F}$ with constant discharge rates $\ldots \ldots \ldots \ldots$

17 Storage tank outlet temperatures for controlled tank inlet temperature of $60^{\circ} \mathrm{F}$ with constant discharge rates $\ldots \ldots \ldots \ldots$ 
vii

\section{LIST OF TABLES}

$\begin{array}{lll}\text { Table } & \text { Page }\end{array}$

1 ISTF monitoring points for the Transphase eutectic system . . . . . 6

2 Transphase charge test conditions .................. 19

3 Transphase charge test summary . . . . . . . . . . . . 20

4 Transphase discharge test summary . . . . . . . . . . . . . 27 


\section{ABBREVIATIONS AND SYMBOLS}

$\begin{array}{ll}\text { cap }_{\mathrm{h}} & \begin{array}{l}\text { discharge capacity measured at heater } \\ \text { cap }_{\mathrm{t}}\end{array} \\ \mathrm{C}_{\mathrm{p}} & \begin{array}{l}\text { discharge capacity measured at storage tank } \\ \text { specific heat }\end{array} \\ \text { EPRI } & \text { direct expansion } \\ \text { FE1 } & \begin{array}{l}\text { Electric Power Research Institute } \\ \text { refrigerant mass flow to the expansion valves }\end{array} \\ \text { FE3 } & \text { brine flow to storage tank } \\ \text { FE4 } & \text { brine flow to the heater } \\ \text { FE5 } & \text { refrigerant volumetric flow to the condenser } \\ \text { FE6 } & \text { water flow rate } \\ \text { gPm } & \text { gallons per minute } \\ \text { HE1 } & \text { refrigerant enthalpy entering the condenser } \\ \text { HE2 } & \text { refrigerant enthalpy leaving the condenser } \\ \text { HE10 } & \text { enthalpy corresponding to the measured suction temperature and pressure } \\ \text { of the superheated refrigerant leaving the chiller/evaporator } & \text { Ice Storage Test Facility } \\ \text { ISTF } & \text { compressor energy and power } \\ \text { JE1 } & \text { brine pump energy and power } \\ \text { JE3 } & \text { heater energy and power } \\ \text { JE10 } & \text { sodium hydroxide } \\ \text { NaOH } & \text { outer diameter } \\ \text { OD } & \text { Oak Ridge National Laboratory } \\ \text { ORNL } & \text { Phase Change Material } \\ \text { PCM } & \text { compressor discharge pressure } \\ \text { PE1 } & \text { condenser outlet refrigerant pressure } \\ \text { PE2 } & \text { chiller inlet refrigerant pressure } \\ \text { PE4 } & \text { chiller inlet refrigerant pressure } \\ \text { PE5 } & \text { compressor suction pressure } \\ \text { PE10 } & \text { psi }\end{array}$


$\dot{Q}_{\mathrm{f}} \quad$ heat rejected by the refrigerant

$\mathrm{Re}_{\mathrm{b}} \quad$ refrigeration effect as determined by measured brine flow rate and temperature change at cool storage tank

$\mathrm{Re}_{\mathrm{bch}} \quad$ refrigeration effect as determined by measured brine flow rate and temperature change at chiller/evaporator

$\mathrm{RE}_{\text {fch }}$ refrigeration effect as determined by measured refrigerant flow rates and thermodynamic properties

SG specific gravity

$\mathrm{T}$

temperature

TE1

compressor discharge temperature

TE2

condenser discharge temperature

TE4

chiller inlet refrigerant temperature

TE5

chiller inlet refrigerant temperature

TE10

compressor suction temperature

TE11

brine temperature entering heater

TE12

brine temperature leaving heater

TE14

storage tank outlet brine temperature

TE15

brine temperature leaving the storage tank

TE16

brine temperature entering the storage tank

TE17

brine temperature leaving the chiller/evaporator

TE18

brine temperature entering the chiller/evaporator

TE19

water temperature entering the condenser

TE20

water temperature exiting the condenser

ton

12,000 Btu/h

T-h

ton-hour

$\rho$

density

$\tau$

time 


\section{ACKNOWLEDGMENTS}

This important research has been made possible by the support of the Electric Power Research Institute. I would like to thank the program manager, Ronald Wendland, for his critical support and enthusiasm. Transphase, Inc. provided the cool storage unit for testing. John Tomlinson of Oak Ridge National Laboratory designed the Ice Storage Test Facility, supervised its construction, and has provided valuable guidance during the testing process. Delmar Fraysier is the chief operator of the test facility and made important contributions to the test procedures. 


\title{
TRANSPHASE COOL STORAGE TEST REPORT*
}

\author{
Therese K. Stovall
}

\begin{abstract}
The Ice Storage Test Facility (ISTF) is designed to test commercial cool storage systems. Transphase, Inc. provided a prototype of a new storage tank design equipped with coils designed for use with a secondary fluid system and filled with a eutectic designed to freeze at $41^{\circ} \mathrm{F}$. The Transphase cool storage system was tested over a wide range of operating conditions. Measured system performance during charging showed the ability to freeze the tank with relatively constant brine temperatures over most of the charging cycle. During discharge cycles, the storage tank outlet temperature was governed mainly by the brine flow rate and the tank's remaining charge. The discharge capacity was dependent upon both the selected discharge rate and maximum allowable tank outlet temperature. This prototype unit experienced several operational problems, not unexpected for the first fullsize execution of a new design. Such prototype testing was one of EPRI's primary goals in founding the ISTF.
\end{abstract}

\section{INTRODUCTION}

Commercial air-conditioning loads are a large component of the afternoon peak loads served by electric utilities. Increased use of cool storage would shift this electrical load from peak to off-peak periods. This shift would permit utilities to defer construction of additional generating capacity and reduce customers' demand charges.

Although the number of cool storage installations in commercial buildings is growing, it represents only a small fraction of the potentiai market. One major barrier to the use of cool storage equipment has been the uncertainty associated with its performance. Uniform testing by an independent agency has not been available. The performance data available

"Units used throughout this report are common to and exclusive in the industry. 
from manufacturers are varied in scope and detail from one type of device to another and across manufacturers as well. Often system performance values are given for only one operating point, making it difficult to predict performance under other operating conditions.

The Electric Power Research Institute (EPRI) therefore sponsored the development of an Ice Storage Test Facility (ISTF) in 1985 to permit uniform testing of commercial-size cool storage equipment of many different types. This testing serves two purposes: (1) to provide uniform performance test results and (2) to promote system improvements based on experimental data. Uniform test results will be useful to utilities in promoting cool storage installation and use and in requesting rate incentives from public utility commissions and to building designers in specifying appropriate equipment for their applications. The experimental data will also be useful to equipment designers because it will describe component behavior as well as overall system performance. The capacity of the ISTF was sized at $250 \mathrm{~T}$-h, large enough to test most commercially available units. Real-time data acquisition and precise computer controls were included.

The ISTF can be used to test dynamic, liquid recirculation, secondary fluid, and direct expansion (DX) ice makers. The simplest ice maker is a DX machine. In a DX ice maker, the refrigerant is sent as a cold liquid into coils submerged in a tank of water. As the refrigerant passes through these coils it absorbs heat from the water and evaporates. As the refrigerant leaves the coils it is completely gaseous and usually slightly superheated. The water in the tank is thereby chilled until it becomes frozen. When the stored cooling is needed, the ice is melted by circulating warm water from the heat load through the ice and returning the chilled water to the heat load. This arrangement is called an exterior melt because the ice is melted from the surface opposite from where it is formed.

In a secondary fluid system, the cold liquid refrigerant is sent to a heat exchanger outside the tank of water. In this heat exchanger, a secondary fluid, typically a glycol mixture, is chilled. This secondary fluid is sent to the tank of water where it absorbs heat from the water, again freezing the water in the tank. The secondary fluid can also be used to transfer the stored cooling to the heat load. This arrangement is called an internal melt. 
The stored cooling energy can also be transferred to the heat load by using an external melt as described for the DX system.

A liquid recirculation system is similar to the DX system because the cold refrigerant is sent to coils submerged in the tank of water. However, in the liquid recirculation system, the amount of refrigerant circulated through the coils is typically two to three times greater than in a DX system so that only a portion of the refrigerant is evaporated and the coils remain wetted throughout their length for improved heat transfer. This additional refrigerant circulation is accomplished through the use of gravity feed or a refrigerant pump. The stored cooling energy is transferred to the heat load using an external melt arrangement.

A dynamic ice maker freezes ice using either a DX or a liquid overfeed arrangement. However, in a dynamic system, the ice is harvested on a periodic basis by a defrosting cycle. This harvesting cycle reduces the ice thickness on the heat transfer surface of the chiller. After the ice is harvested, it is stored in a slush or slurry of ice and water. The water is circulated to provide the stored cooling to the heat load.

This report describes the test results for a cool storage tank furnished by Transphase, Inc. The Transphase storage tank holds a eutectic that freezes at a warmer temperature than water and is both charged and discharged using a secondary fluid or brine. The Transphase storage system and the test facility are described in Sect. 2. Section 3 describes the tests that were performed to characterize the storage system, and Sect. 4 describes the analysis methods used to evaluate the performance data. The results and recommendations are summarized in Sects. 5 and 6. 


\section{SYSTEM DESCRIPTION}

\subsection{TRANSPHASE STORAGE SYSTEM}

Transphase has marketed cool storage systems based on various eutectics, providing a range of storage temperatures. In the past, their systems have circulated brine around stationary containers. The system tested at the ISTF was a significant departure from these previous designs. This system circulated brine through heat exchanger tubing within a large tank containing a eutectic mixture of $\mathrm{NaOH}$ and water with a freezing temperature of $41^{\circ} \mathrm{F}$. The unit tested was the largest prototype of this new design with a capacity of $250 \mathrm{~T}$-h. As described earlier, testing such new designs was one of EPRI's primary goals in founding the ISTF.

The cool storage tank tested was a horizontal cylinder with an external header arrangement along the length of the top of the tank. The eutectic within the tank is chilled by the flow of brine through 1/2-in.-OD plastic tubing, arranged in nine circular bundles within the tank. These tubes are arranged in concentric coils and almost completely submerged in the eutectic fluid. The brine used for these tests was a mixture of ethylene glycol and water with a freezing point of $10^{\circ} \mathrm{F}\left( \pm 2^{\circ} \mathrm{F}\right)$. The Transphase storage tank is discharged by circulating the brine through the tank and then through the desired heat load, simulated by a heater in the test facility. During an initial leak test, the tank was filled with 4,660 gal. of water. This water was drained and the tank was filled with 4,582 gal. of the eutectic mixture. This filled the tank to a level approximately three in. below the tops of the coils. The volume of brine in the storage system coils was estimated to be 580 gal., based on the amount of brine pumped into the tank and the nearby piping. However, as is discussed later in this report, this amount may be in error due to the difficulty in removing air from the Transphase coils (causing the volume to be under-estimated) and due to brine leakage which would cause an over-estimate of the coil volume. 


\subsection{TEST FACILITY}

The test facility was designed to test a wide variety of storage systems. It includes all refrigeration system components necessary to charge brine systems. Figure 1 shows the test facility configuration used to test the Transphase storage tank equipped with the brine coils. The test facility is well-equipped with monitoring devices to measure temperature, pressure, flow, and energy use. The monitoring points shown in Fig. 1 are listed in Table 1. The test loop instrumentation is described more fully in Appendix A and Ref. 1.

A variable speed pump was used to circulate brine during both the charge and discharge cycles, as is shown in Fig. 1. The evaporator/chiller (see Fig. 1) connects the test facility's refrigeration system to the brine loop that charges the cool storage tank. In the evaporator/chiller, a refrigerant, HCFC-22, is vaporized, absorbing heat from the brine. To accommodate the desired wide range of testing conditions, a chiller with two independent

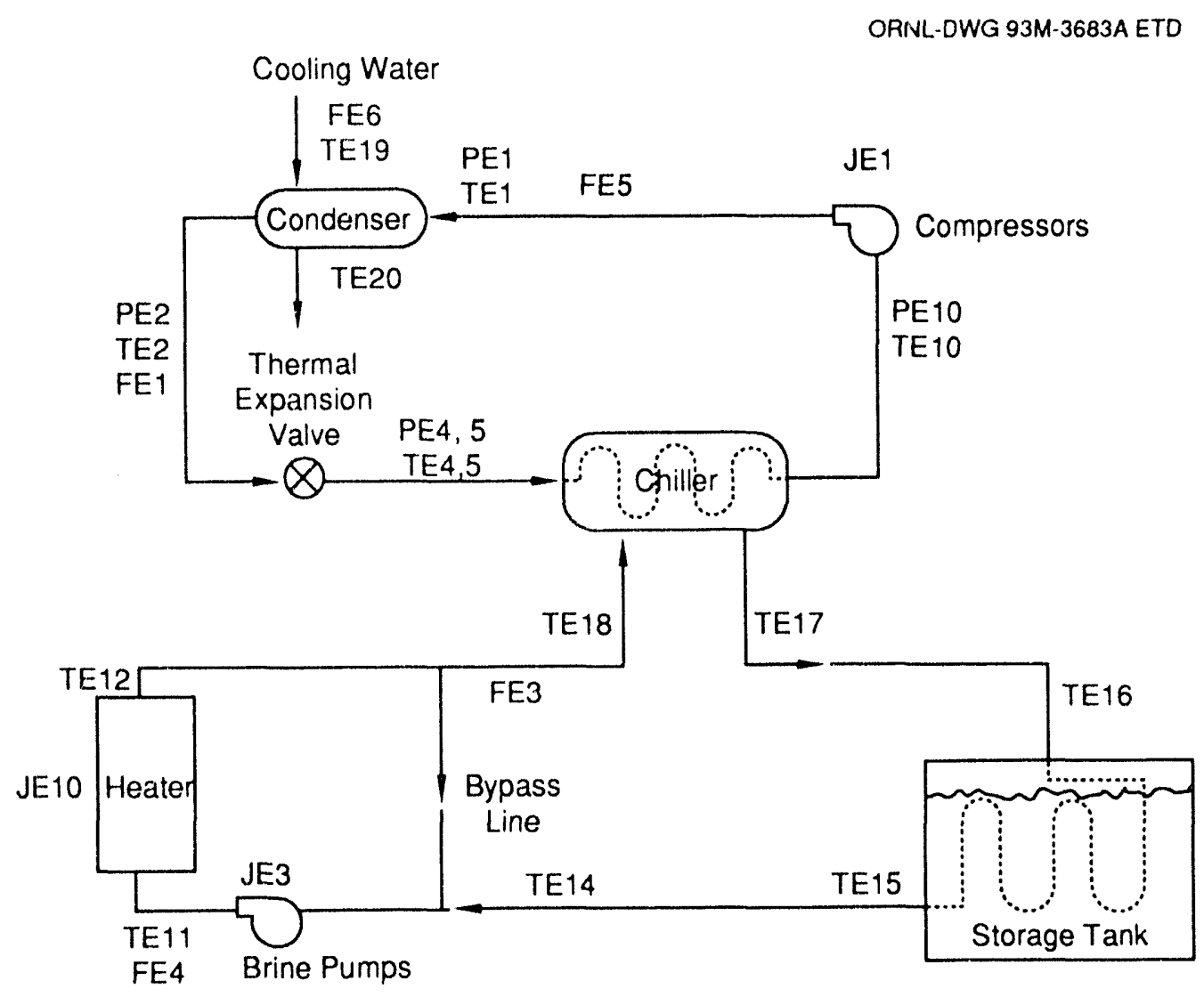

Fig. 1. ISTF schematic for Transphase storage system. 
Table 1. ISTF monitoring points

for the Transphase eutectic system

\begin{tabular}{cl}
\hline Point label & \multicolumn{1}{c}{ Measured quantity } \\
\hline FE1 & Chiller inlet flow, refrigerant, mass \\
FE3 & Chiller inlet flow, brine \\
FE4 & Brine pump discharge flow \\
FE5 & Compressor outlet flow, volume \\
FE6 & Condenser inlet water flow \\
JE1 & Compressor energy and power \\
JE3 & Brine pump energy and power \\
JE10 & Heater energy and power \\
PE1 & Compressor discharge pressure \\
PE2 & Condenser outlet refrigerant pressure \\
PE4 & Chiller inlet refrigerant pressure \\
PE5 & Chiller inlet refrigerant pressure \\
PE10 & Compressor suction pressure \\
TE1 & Compressor discharge temperature \\
TE2 & Condenser discharge temperature \\
TE4 & Chiller inlet refrigerant temperature \\
TE5 & Chiller inlet refrigerant temperature \\
TE10 & Compressor suction temperature \\
TE11 & Heater inlet water temperature \\
TE12 & Heater outlet water temperature \\
TE14 & Storage tank outlet brine temperature \\
TE15 & Storage tank outlet brine temperature \\
TE16 & Storage tank inlet brine temperature \\
TE17 & Chiller outlet brine temperature \\
TE18 & Chiller inlet brine temperature \\
TE19 & Condenser inlet water temperature \\
TE20 & Condenser outlet water temperature \\
\hline & \\
&
\end{tabular}

and equal-size refrigerant coils was selected. The control system is designed to select one or both chiller coils based on the compressor loading. The thermal expansion valves feeding refrigerant to these coils open and close in response to the measured superheat at the coil exit. Two parallel compressors with part-load capabilities are used to vary the nominal chiller capacity from 15 to 95 tons. The flow of water to the condenser controls the condensing temperature between 80 and $100^{\circ} \mathrm{F}$. The brine pump speed was varied to control the brine flow rate at the selected value during the charge cycle. The bypass line 
was always closed during the charge tests. During discharge cycles, the brine pump speed, heater power, and bypass valve positions are used to control test conditions. 


\section{SYSTEM TESTS}

All units tested at the ISTF are examined for their operational characteristics. However, because the Transphase unit was a prototype unit, this aspect of the testing received additional attention. Performance tests were also planned, similar to those used for ice storage systems. These test plans are based on Ref. 1, modified as necessary to reflect the elevated melting temperature of the eutectic mixture.

The test plan was structured to test the storage tank's capabilities under a wide range of operating conditions. Transphase expected the tank to work well with brine flow rates between 50 and $200 \mathrm{gpm}$, with the most efficient flow rate being between 80 and $120 \mathrm{gpm}$. The charging tests were designed to determine how the storage system would respond to charging periods from 6 to $14 \mathrm{~h}$ and brine flow rates from 50 to $200 \mathrm{gpm}$.

The discharge tests emulated discharge periods ranging from 7 to $12 \mathrm{~h}$ with varying temperature and flow requirements at the heater. For most tests, the temperatures at the heater inlet and outlet were maintained for a constant heater power by varying the brine flow to the storage tank. The tank was considered to be fully discharged when it was no longer possible to maintain the desired heater outlet temperature. Some latent storage may remain in the tank at that time but is unavailable to meet the load. A few tests were made at a constant brine flow rate through the heater and storage tank; i.e., the brine temperatures at the heater were not controlled. One test was also made with a constant heater outlet temperature, constant brine flow, and variable heater power.

Storage tank shell heat gains were not measured because this prototype was not insulated by the manufacturer. The main steel storage tank was surrounded with a plastic tank for leak containment purposes. However, this provided no substantial insulation, as was shown by the large amount of condensation on the tank skin whenever the tank was cooler than ambient. 


\section{ANALYSIS METHODOLOGY}

The primary concern of the data analysis is to produce useful information and to present it in a meaningful fashion. Another concern is to distinguish between the performance of the cool storage system and the performance of the refrigeration system. While analysis of the refrigeration system performance can prove enlightening and is certainly useful to system designers, it must be distinguished from that of the manufacturer's storage system.

\subsection{DATA PROCESSING}

The data available for each operational test permit redundant calculations that increase our understanding and confidence in the test results. For example, the refrigeration effect is measured at the chiller on both the brine and refrigerant sides. The refrigeration effect to the storage tank is measured by the brine flow and temperature change. The energy available for discharge is measured by brine flow and temperatures at the heater and at the storage tank, as well as by the power going to the discharge heater. This duplication of measurements also enables us to fully separate the performance of the cool storage system from that of the refrigeration system.

The data are collected for each monitoring point every $30 \mathrm{~s}$. This collection frequency is dictated by system control requirements rather than by the analysis requirements. The data are immediately summed (for flows or energy uses) or averaged (for temperatures, pressures, power uses, and flow rates) to represent the appropriate values on a 5-min basis.

Thermodynamic properties for HCFC-22 are calculated from a computerized format developed by G. T. Kartsounes and R. A. Erth and adapted for use at Oak Ridge National Laboratory (ORNL) by C. K. Rice and S. K. Fischer. ${ }^{2}$ Brine properties, as a function of concentration and temperature, were provided by Union Carbide Corporation, and information for the temperature range of interest was extracted. ${ }^{3}$ 


\subsection{REFRIGERATION EFFECT}

The stored cooling effect at the storage tank is calculated from the measured brine flow rate and temperature gain as is shown in Eq. (1).

$$
R_{b}=F E 3 \times c_{p} \times \rho \times(T E 15-T E 16),
$$

where

$$
\begin{aligned}
\mathrm{RE}_{\mathrm{b}} & =\text { refrigeration effect produced by the brine, } \\
\mathrm{FE} 3 & =\text { brine flow from the chiller, } \\
\mathrm{c}_{\mathrm{p}} & =\text { brine specific heat, } \\
\rho & =\text { brine density, } \\
\mathrm{TE} 15 & =\text { brine temperature leaving the storage tank, and } \\
\mathrm{TE} 16 & =\text { brine temperature entering the storage tank. }
\end{aligned}
$$

The brine specific heat and specific gravity are provided in the form of families of curves in Ref. 3. Interpolations from these curves for the temperature range from 20 to $60^{\circ} \mathrm{F}$ and a brine concentration of $25 \mathrm{wt} \%$ produced the following equations for specific gravity (relative to water at $60^{\circ} \mathrm{F}$; and specific heat.

$$
\begin{gathered}
S G=(-0.000108) \times T+1.0482, \\
c_{p}=0.000275 \times T+0.922 .
\end{gathered}
$$

where

$$
\begin{aligned}
S G & =\text { specific gravity } \\
T & =\text { average brine temperature }\left({ }^{\circ} \mathrm{F}\right), \text { and } \\
c_{p} & =\text { specific heat }\left[\mathrm{Btu} /\left(\mathrm{lb}-{ }^{\circ} \mathrm{F}\right)\right] .
\end{aligned}
$$

The system capacity was also measured at the evaporator/chiller, on both the brine and refrigerant sides. These measurements provide another checkpoint to guard against instrument failure. The capacity measured at the chiller is expected to be slightly higher 
than that at the storage tank due to shell heat gains at the tank and in the piping and also by the amount of energy added by the brine pumps. The brine-side measurements are similar to those used for the storage tank and are shown in Eq. (4). The refrigerant-side measurements are used in Eq. (5). Shell losses from the well-insulated chiller are assumed to be negligible.

$$
\mathrm{RE}_{\mathrm{bch}}=\mathrm{FE} 3 \times \mathrm{c}_{\mathrm{p}} \times \rho \times(\mathrm{TE} 18-\mathrm{TE} 17),
$$

where

$$
\begin{aligned}
\mathrm{RE}_{\mathrm{bch}}= & \text { refrigeration effect at the chiller, based on brine flow and temperature } \\
& \text { measurements, } \\
\mathrm{FE} 3= & \text { brine flow from the chiller, } \\
\mathrm{c}_{\mathrm{p}}= & \text { brine specific heat, } \\
\rho & =\text { brine density } \\
\mathrm{TE} 17= & \text { brine temperature leaving the chiller, and } \\
\mathrm{TE} 18= & \text { brine temperature entering the chiller. }
\end{aligned}
$$

$$
\mathrm{RE}_{\mathrm{fch}}=\mathrm{FE} 1 \times(\mathrm{HE} 10-\mathrm{HE} 2),
$$

where

$$
\begin{aligned}
& \mathrm{RE}_{\text {ch }}=\text { refrigeration effect at the chiller, based on refrigerant flow and } \\
& \mathrm{FE} 1 \text { = refrigerant flow to the chiller, } \\
& \text { HE10 = enthalpy corresponding to the measured suction temperature and }
\end{aligned}
$$

\subsection{DISCHARGE ENERGY AVAILABLE}

The cool storage available to meet a cooling load was measured by the brine flow rates and temperature changes at the heater and at the storage tank [see Eqs. (6) and (7)].

$$
\mathrm{cap}_{\mathrm{h}}=\mathrm{FE} 4 \times(\mathrm{TE} 12-\mathrm{TE} 11) \times \mathrm{c}_{\mathrm{p}} \times \rho,
$$




$$
\mathrm{cap}_{\mathfrak{t}}=\text { FE3 } \times(\text { TE15 }- \text { TE16 }) \times c_{p} \times \rho,
$$

where

$$
\begin{aligned}
\text { cap }_{\mathrm{h}} & =\text { discharge capacity measured at the heater, } \\
\mathrm{FE} 4 & =\text { brine flow to heater, } \\
\mathrm{TE} 12 & =\text { brine temperature leaving heater, } \\
\mathrm{TE} 11 & =\text { brine temperature entering heater, } \\
\mathrm{c}_{\mathrm{p}} & =\text { specific heat of brine, } \\
\mathrm{cap}_{\mathrm{t}} & =\text { discharge capacity measured at the storage tank, } \\
\mathrm{FE} 3 & =\text { brine flow to storage tank, } \\
\mathrm{TE} 15 & =\text { brine temperature leaving storage tank, } \\
\mathrm{TE} 16 & =\text { brine temperature to storage tank, and } \\
\rho & =\text { brine density. }
\end{aligned}
$$

The heater power was also measured but is considered to be less accurate than the other available measurements, as is discussed in Appendix A. 


\section{RESULTS}

\subsection{GENERAL OPERATION}

The brine pressure drop across the Transphase coils was measured at flow rates from 50 to $105 \mathrm{gpm}$ with all nine circuits fully open. The measured pressure drop ranged from $6.5 \mathrm{psi}$ at $50 \mathrm{gpm}$ to $18.5 \mathrm{psi}$ at $105 \mathrm{gpm}$. These values were taken at a brine temperature of $80^{\circ} \mathrm{F}$ and a concentration of $25 \%$. As the brine temperature decreased, the pressure drop increased, as is shown in Fig. 2. The constant-temperature relationship between pressure drop and flow rate shown here doesn't correspond to that expected for either laminar or turbulent flow. An examination of the Reynold's number shows that the brine flow through the heat exchanger is in the transition region between laminar and turbulent flow whenever the overall flow rate is between 50 and $190 \mathrm{gpm}$.

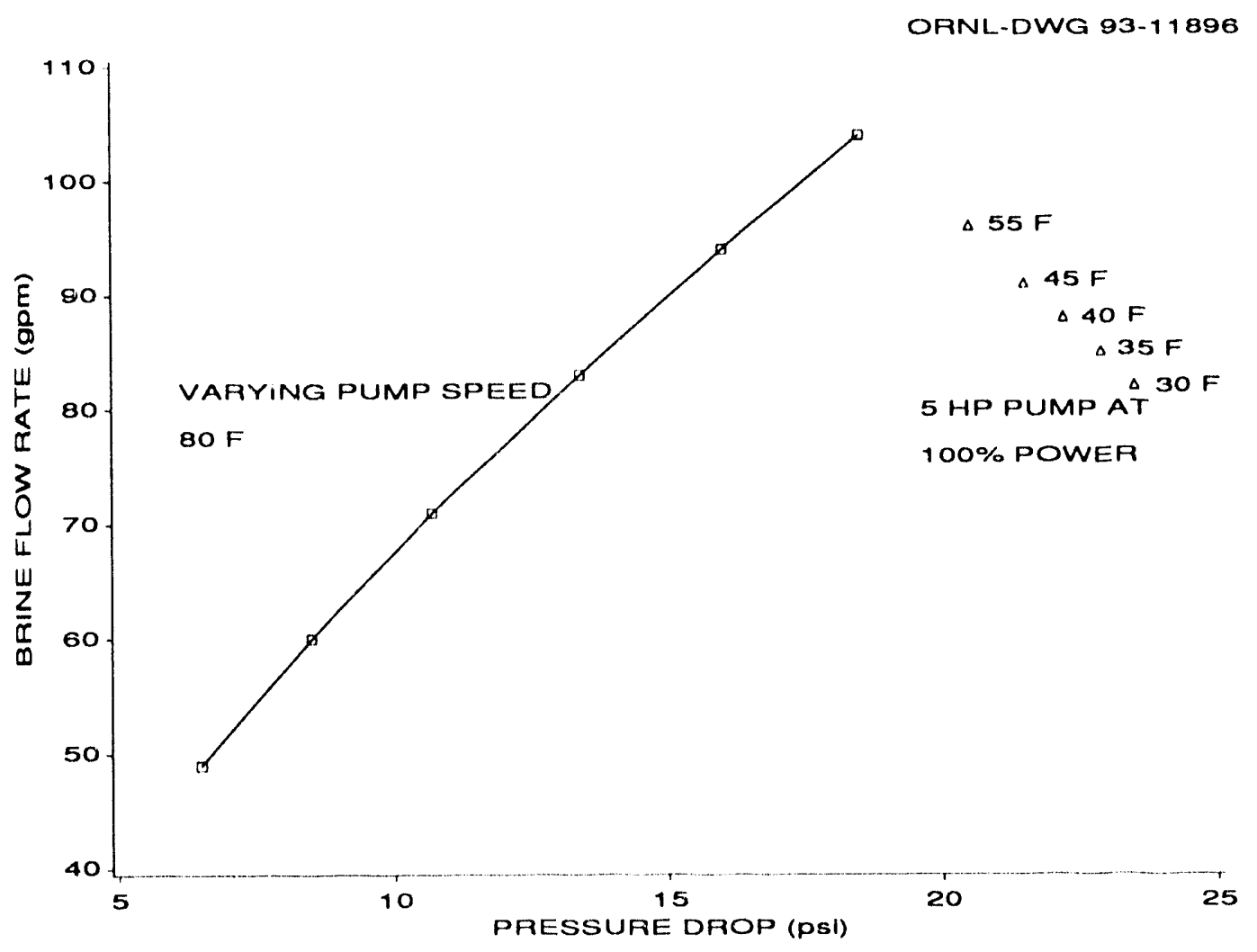

Fig. 2. Transphase storage tank heat exchanger pressure drop with all nine circuits open for $25 \%$ glycol brine. 
Some operational difficulties were encountered with this prototype unit. The method of joining the heat exchanger tubing to the header apparatus resulted in a large number of leaks. Most of these leaks were very small and difficult to locate, but a few leaks were large enough to produce spurting jets of brine. Because of leaks, one to two circuits (out of nine) were closed off for most tests, effectively reducing the available heat exchanger surface area by -10 tr. $20 \%$. Al'hough the circuit shut-off valves isolated the worsi leaks and the brine loop was depressurized whenever the unit was shut down, leaks continued. These continuing leaks made it necessary to add brine at the start of every charge cycle. Over the four-month trial period, $66 \mathrm{gal}$ of brine were added to make up for leakage. Some of the leaking brine ran off the tank exterior and some was caught with a series of tubes and beakers. However, most of the leaking brine fell down into the Transphase tank and floated on top of the eutectic mixture, where it was visible as a greenish coating. If this unit had been installed in an underground location, the leaking brine would eventually have caused the caustic material in the tank to overflow, as was observed at the test facility during the final tests. A redesign of the header connections and a rigorous quality control program to eliminate these leaks should be implemented.

The Transphase heat exchanger tubing is arranged in a large number of coils around a horizontal axis. This creates a large number of high points where air bubbles can become trapped and are impossible to vent. It becomes necessary to circulate the brine for extended periods of time to purge the system of air. It is particularly easy to trap air in the heat exchanger tubing in the process of initially filling the Transphase heat exchanger with brine. If a low volume brine transfer pump is used, the coils can become air-locked. A high volume pump is therefore required for this initial fill.

With mixtures there is the potential for phase separation of the components, especially when freezing or melting on surface heat exchangers. As a result, the temperatures throughout the tank will not be uniform at each time step. Because of this, there is the potential for chemical nonuniformities developing in the tank so there may be a gradual loss in storage capacity. This loss in capacity would probably not be noticed in short-term thermal tests but would be noticeable in actual installations as cycling proceeds. Therefore, the mixture was sampled at several points during the testing process to study this 
effect. Laboratory analysis of the composition of these samples indicates that there may be a long term concern. Figure 3 shows the measured caustic concentration for a number of samples. The first sample was taken after the initial fill, before the caustic was ever frozen, and tested at $45.86 \%$ caustic. The caustic supplier tested the material at $46.66 \%$. The supplier was diluting the caustic from a standard 50\% strength in a large tank and the amount of mixing done before their sample was taken is unknown. Samples taken at a single point, 10 in. below the surface of the caustic in the tank, over a one month period (over four freeze and melt cycles) decreased from $45.66 \%$ to $45.23 \%$. A stronger indication of a separation effect is found in a sample removed from the bottom of the tank five months after the initial fill. This bottom sample tested at $50.2 \mathrm{wt}$.\% caustic, a significant increase in concentration.

The stratification and changes in concentration could be due to the partial separation of the two solid phases that are in equilibrium when the $\mathrm{NaOH}-\mathrm{H}_{2} \mathrm{O}$ drops below its eutectic

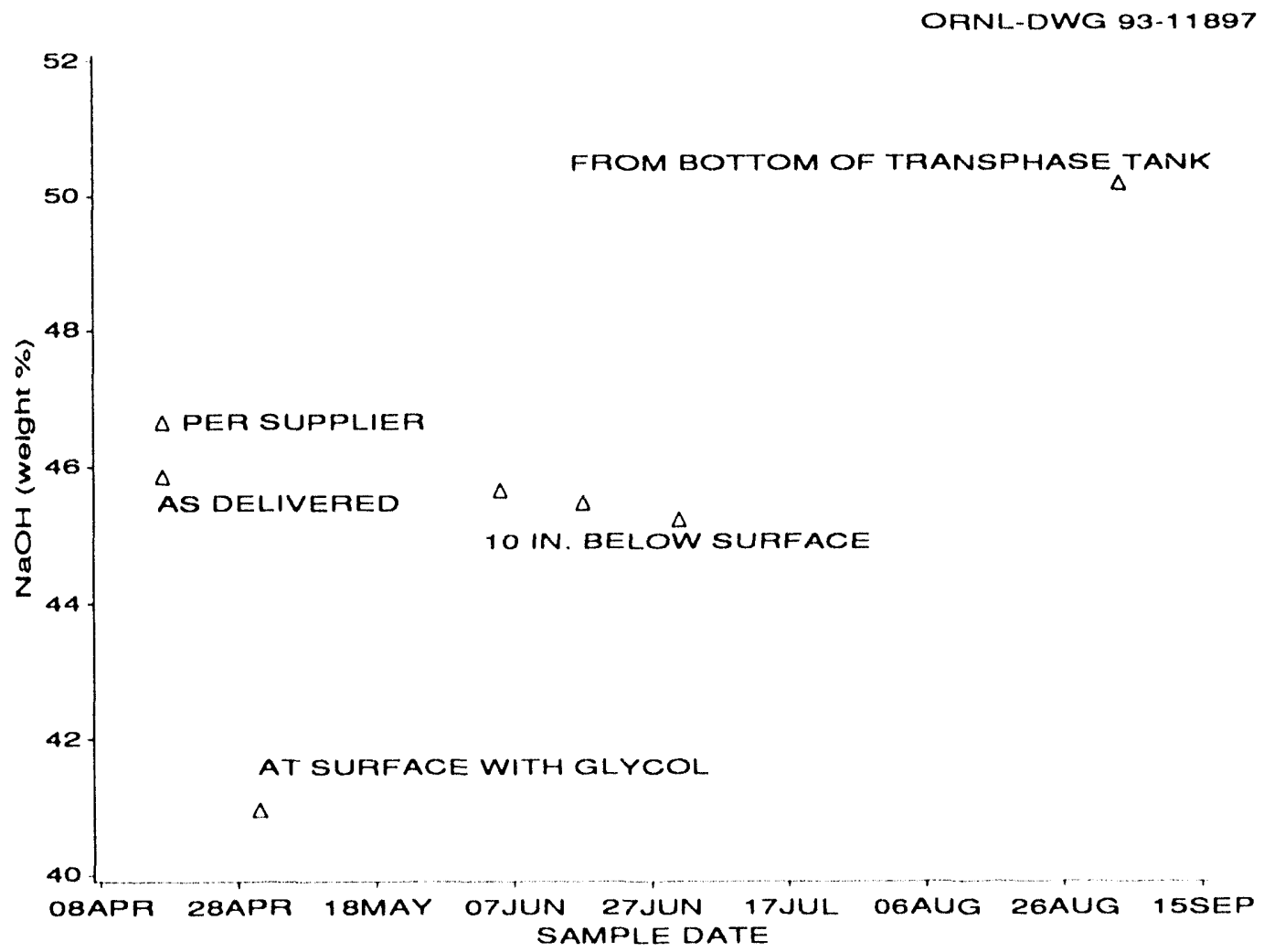

Fig. 3. Caustic concentration in the Transphase storage tank. 
point of $41^{\circ} \mathrm{F}$ for the nominal $47 \%$ concentration. Figure 4 , an $\mathrm{NaOH} / \mathrm{H}_{2} \mathrm{O}$ phase diagram taken from Ref. 4, shows that these solid phases consist of $\mathrm{NaOH} \cdot 3 \frac{1}{2} \mathrm{H}_{2} \mathrm{O}$ and $\mathrm{NaOH} \cdot 2 \mathrm{H}_{2} \mathrm{O}$. If a portion of the denser crystals $\left(\mathrm{NaOH} \cdot 2 \mathrm{H}_{2} \mathrm{O}\right)$ settle out during each freeze cycle, the $\mathrm{NaOH}$ concentration at the bottom of the tank will gradually increase. Such a stratification will eventually affect the freezing point of the mixture. A slight drop $\left(-1^{\circ} \mathrm{F}\right)$ in the $\mathrm{NaOH}$ freezing temperature was seen in ISTF tests from May 22 to Jline 26 and is shown in Fig. 5. The temperatures shown in Fig. 5 were taken -21 in. below the surface of the caustic, approximately $1 / 3$ of the way from one end of the tank. This figure shows the $\mathrm{NaOH}$ temperature as it recovers from the initial sub-cooling and reaches a relatively stable plateau. Each of the tests shown in Fig. 5 began from the fully melted state. It is not known whether this change in freezing temperature is due to a change in the caustic concentration or to the small amount of brine spilled into the system.

The effect of the spilled glycol on this caustic stratification is unknown. Under proper operating conditions, there would be no glycol within the caustic mixture. However, a surface sample taken soon after the first leaks were noticed showed a glycol concentration of $1.6 \mathrm{wt} . \%$ ( $\pm 0.5 \mathrm{wt} . \%)$ and a reduced caustic concentration of $40.96 \mathrm{wt} . \%$. It's not clear to what extent the glycol permeated the caustic mixture. The glycol specific gravity was much lower than that of the caustic mixture, and the glycol would therefore be expected to float, considering the much higher viscosity of the caustic mixture and the absence of any physical mixing device. Indeed, the series of samples taken $10 \mathrm{in}$. below the surface showed only very small amounts when tested for glycol, registering from $0.2 \mathrm{wt} . \%( \pm 0.2)$ to $0.3 \mathrm{wt} \%( \pm 0.3)$. Another factor to be considered is the presence of a nucleating agent within the tank. Although this agent is supposed to be physically restrained from mixing with the caustic, the initial sample taken near the top of the tank showed trace amounts of 26 ppm. A final sample taken from the bottom of the tank showed a much higher concentration of $100 \mathrm{ppm}$.

As currently designed, the Transphase system has a drain plug on the bottom of the cylindrical storage tank. Although draining the caustic would not be a part of normal operation, it could become necessary for heat exchanger repairs. This bottom drain was found to be unusable at the end of the ISTF tests and it was necessary to pump the caustic 


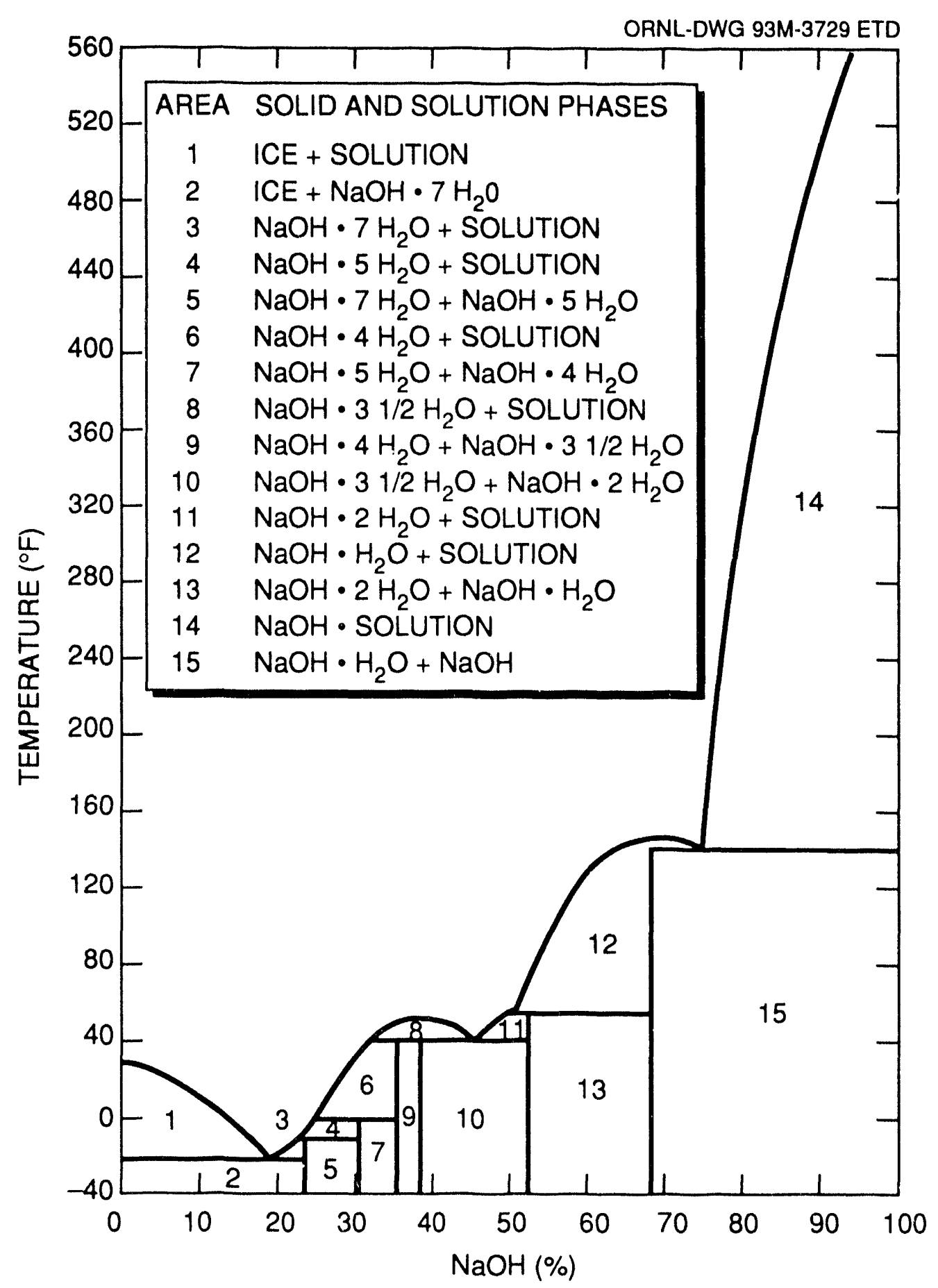

Fig. 4. $\mathrm{NaOH} / \mathrm{H}_{2} \mathrm{O}$ phase diagram 


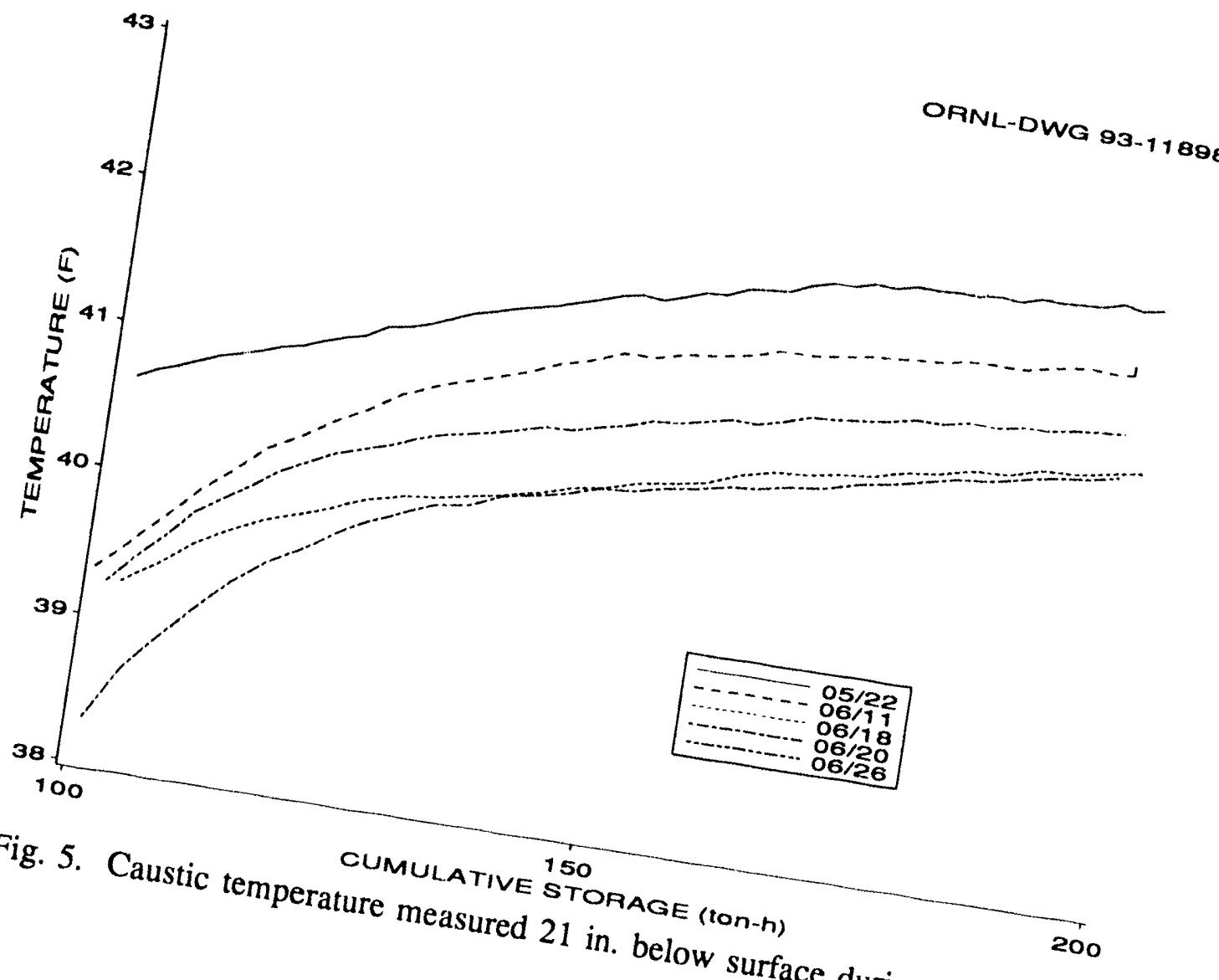
sludge made up of slowly accumulating settled solid impurities. be usable, it should be redesigned to include a solid impurities. ${ }^{5}$ For the bottom drain to storage tank. The drain could also be relocade a short length of pipe extending drain to a short distance above the botlom be relocated to the end wall of the tank. The Transphase tank is not the tank. meter. This makes it difficult to not equipped with any kind of the is available at the start of the assure a full tank of solid of thermal storage inventory series of partial charge/discharge cycle. This problem brine temperature durinischarge cycles. The only indieation was most noticeable after a temperature shows a maring the charge cycle. As will be indication of charge available is the we found that it is this arked drop as the tank approall be described later in this report, 
be used to judge whether the tank is fully charged. This is especially true under experimental conditions with variable charge rates and variable brine flow rates.

\subsection{CHARGING PERFORMANCE}

When designirig a thermal storage system fur a given application, the heat rujection temperature, storage capacity, and time available for charging are usually known. ${ }^{6}$ This establishes the average capacity needed during the charging cycle. The ability of a storage system to meet these requirements is a function of both the storage tank/coil design and of the balance of the refrigeration system, most importantly the compressor. A large number of tests were made to measure the Transphase charging performance. These tests are summarized in Tables 2 and 3.

Table 2. Transphase charge test conditions

\begin{tabular}{|c|c|c|c|c|c|c|}
\hline $\begin{array}{l}\text { Test } \\
\text { ID }\end{array}$ & $\begin{array}{c}\text { Initial } \\
\text { condition }\end{array}$ & $\begin{array}{c}\text { Compressor } \\
\text { loading } \\
\text { (hp/\%) }\end{array}$ & $\begin{array}{l}\text { Circuits } \\
\text { in use }\end{array}$ & $\begin{array}{l}\text { Condensing } \\
\text { temperature } \\
\left({ }^{\circ} \mathrm{F}\right)\end{array}$ & $\begin{array}{c}\text { Brine } \\
\text { flow rate } \\
(\mathrm{gpm})\end{array}$ & $\begin{array}{l}\text { Brine } \\
\text { temperature } \\
\text { change in } \\
\text { ice tank } \\
\left({ }^{\circ} \mathrm{F}\right)\end{array}$ \\
\hline 0425 & Melted & $40 / 50$ & 9 & 95 & 87 & 3.9 \\
\hline 0508 & Melted & $40 / 75$ & 9 & 90 & 71 & 8.0 \\
\hline 0522 & Melted & $40 / 100$ & 7 & 95 & 94 & 6.3 \\
\hline 0528 & Melted & $40 / 100$ & 9 & 95 & 49 & 10.6 \\
\hline 0530 & $\begin{array}{l}\text { Some solid } \\
\text { PCM }\end{array}$ & $40 / 75$ & 8 & 94 & 77 & 6.6 \\
\hline 0606 & $\begin{array}{l}\text { Some solid } \\
\text { PCM }\end{array}$ & $40 / 100$ & 7 & 91 & 91 & 5.2 \\
\hline 0611 & Melted & $75 / 100$ & 7 & 99 & 91 & 8.7 \\
\hline 0618 & Melted & $75 / 100$ & 8 & 80 & 99 & 9.7 \\
\hline 0620 & Melted & $\begin{array}{c}75 / 100 \text { and } \\
40 / 75\end{array}$ & 8 & 100 & 98 & 9.0 \\
\hline 0626 & Melted & $75 / 75$ & 8 & 94 & 100 & 7.3 \\
\hline
\end{tabular}

a Measurement accuracy of $\pm 0.2^{\circ} \mathrm{F}$. 
Table 2 shows initial test conditions in luding whether or not solid PCM was present at the start of the charge test and how many circuits were in use (as discussed in the previous section, some circuits were closed to reduce the amount of brine leakage into the storage tank). By comparing tests made with the same pump settings, the effect of closed circuits on total charging capacity can be estimated. The brine flow rate dropped from 87 to $77 \mathrm{gpm}$ between tests 0425 and 0530 when the number of circuits changed from 9 to 8 . This should cause a capacity derating of $\sim 10 \%$. Tests $0522,0606,0611,0618,0620$, and 0626 were also made with comparable pump settings. This group of tests show that reducing the number of circuits further fror: 8 to 7 drops the brine flow rate, and therefore the capacity, by approximately another $8 \%$. The brine temperature change in the storage tank ranged from a low of $4^{\circ} \mathrm{F}$ to a high of almost $11^{\circ} \mathrm{F}$. With a calibrated RTD accuracy

Table 3. Transphase charge test summary

\begin{tabular}{|c|c|c|c|c|c|c|}
\hline \multirow[b]{2}{*}{$\begin{array}{l}\text { Test } \\
\text { ID }\end{array}$} & \multirow[b]{2}{*}{$\begin{array}{c}\text { Test } \\
\text { duration } \\
\text { (h) }\end{array}$} & \multirow{2}{*}{$\begin{array}{l}\text { Average } \\
\text { charging } \\
\text { rate } \\
\text { (ton) }\end{array}$} & \multirow{2}{*}{$\begin{array}{c}\text { Average } \\
\text { chiller } \\
\text { capacity } \\
\text { - pump heat } \\
\text { (ton) }\end{array}$} & \multirow[b]{2}{*}{$\begin{array}{l}\text { Total } \\
\text { charge" } \\
\text { (ton-h) }\end{array}$} & \multicolumn{2}{|c|}{$\begin{array}{l}\text { Brine temperature } \\
\text { to tank }\end{array}$} \\
\hline & & & & & $\begin{array}{c}\text { Average } \\
\left({ }^{\circ} \mathrm{F}\right)\end{array}$ & $\begin{array}{l}\text { Minimum } \\
\left({ }^{\circ} \mathrm{F}\right)\end{array}$ \\
\hline 0425 & $25.8^{c}$ & 13.6 & 13.8 & 355 & 37.0 & 32.8 \\
\hline 0508 & $12.7^{\mathrm{c}}$ & 22.8 & 23.1 & 287 & 29.9 & 23.6 \\
\hline 0522 & 10.4 & 23.5 & 23.6 & 246 & 32.0 & 28.7 \\
\hline 0528 & 3.1 & 20.9 & 21.5 & 66 & 31.2 & 26.1 \\
\hline 0530 & $18.8^{\mathrm{c}}$ & 20.7 & 21.2 & 392 & 32.5 & 24.8 \\
\hline 0606 & 14.3 & 19.3 & 19.6 & 279 & 30.8 & 23.4 \\
\hline 0611 & $8.7^{c}$ & 32.0 & 32.4 & 280 & 28.7 & 19.8 \\
\hline 0618 & 7.2 & 38.1 & 38.7 & 276 & 27.2 & 20.6 \\
\hline 0620 & 8.4 & 35.5 & 35.9 & 301 & 28.1 & 18.8 \\
\hline 0626 & $10.3^{c}$ & 29.0 & 29.4 & 305 & 31.4 & 25.7 \\
\hline
\end{tabular}

- From brine flow rate and temperature change in storage tank.

b From brine flow rate and temperature change in the chiller/evaporator minus the pump energy.

c Long tests were interrupted and took place over two or more days. 
of $\pm 0.2^{\circ} \mathrm{F}$, the capacity calculations should show a high degree of accuracy. This is shown by comparing the average capacity measured at the storage tank to the average measured at the chiller (minus the pump energy) as was discussed in Sect. 4.2.1. As Table 3 shows, these values match within $\pm 2 \%$ for every test except the 3-h long test 0528 , which matched within $3 \%$. Over all these charge tests, the agreement averages $99 \%$. A comparison was also made between the refrigerant and brine sides of the chiller/evaporator. All the tests before 0611 showed agreement within $\pm 1 \%$. Tests 0611 to 0626 showed differences between 3 to $10 \%$. This is most likely attributable to some drift in a refrigerant monitor, either flow or temperature. These refrigerant values, especially flow rates, are much more difficult to measure than their brine counterparts. Also, if these later errors were due to a brine measurement error, it would have shown up when comparing the redundant temperature and flow measurement points throughout the loop.

The total charge shown on Table 3 is the product of the average charging rate and the test duration, therefore showing the total amount of cooling provided to the storage tank by the chilled brine flow. However, due to significant jacket losses, this does not represent the total amount of cool storage that might have been available for discharge if the tank had been insulated. The difference between the amount of cooling stored and the amount available during discharge is greatest for those tests made at very low charging rates over a period of several days. This is discussed further in Sect. 5.3.

Compressor capacity depends on suction and discharge pressures and temperatures. When charging an ice-on-coil storage tank, the suction temperature gradually drops as the water in the tank becomes colder and solid ice builds up on the coils. The lower suction temperature leads to a reduced refrigeration capacity. (The Transphase eutectic reduces this penalty by raising the freezing temperature of the storage medium.) The temperature profile of the fluid entering the tank throughout the charge cycle is therefore an important characteristic of the storage system. Figure 6 shows this temperature profile for two freeze tests, both of which started from a fully melted state. The brine inlet and internal $\mathrm{NaOH}$ temperatures (measured 21 in. below the eutectic surface) are plotted against the tank's cumulative charge based on the brine flow rate and temperature change. The second test shown, 0618 , was run at a higher capacity of 38 tons and shows a corresponding lower 


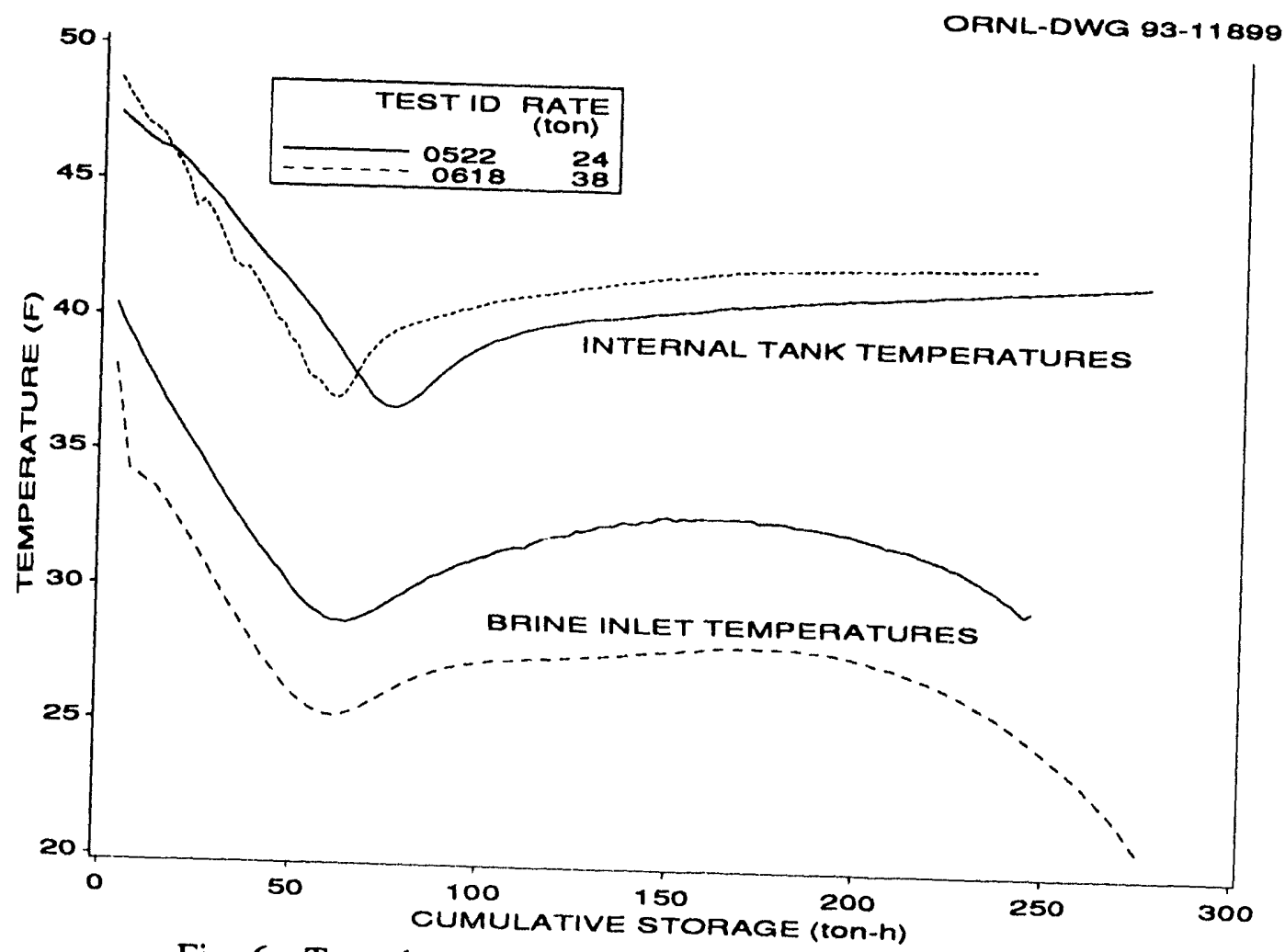

Fig. 6. Two charge tests starting from fully-melted state.

brine inlet temperature (the brine flow rate was nearly the same for these two tests). Both tests show the characteristic brine inlet temperature profile for a fully melted tank. The temperature drops nearly linearly until nucleation occurs after a period of subcooling, seen also in the internal tank temperature profile. The inlet temperature then recovers and begins to increase as the heat transfer surface area expands as solid PCM forms on the tubes. After the solid PCM thickness reaches a certain point, however, the additional heat transfer resistance causes the brine inlet temperature to again drop.

The difference between charging from a fully melted tank and a partially frozen tank can be seen most clearly in Fig. 7. This figure shows two tests run at very nearly the same capacity (20 to 23 tons) and brine flow rates (70 to $77 \mathrm{gpm}$ ). The first test, with test ID number 0508 , began with a fully melted tank. Neglecting the discontinuities due to a test interruption, this profile is similar to in shape to those shown in Fig. 6. Test 0530 began with some solid PCM present in the storage tank, and shows a very different profile. The subcooling is very nearly eliminated for this case and both the brine inlet and internal 


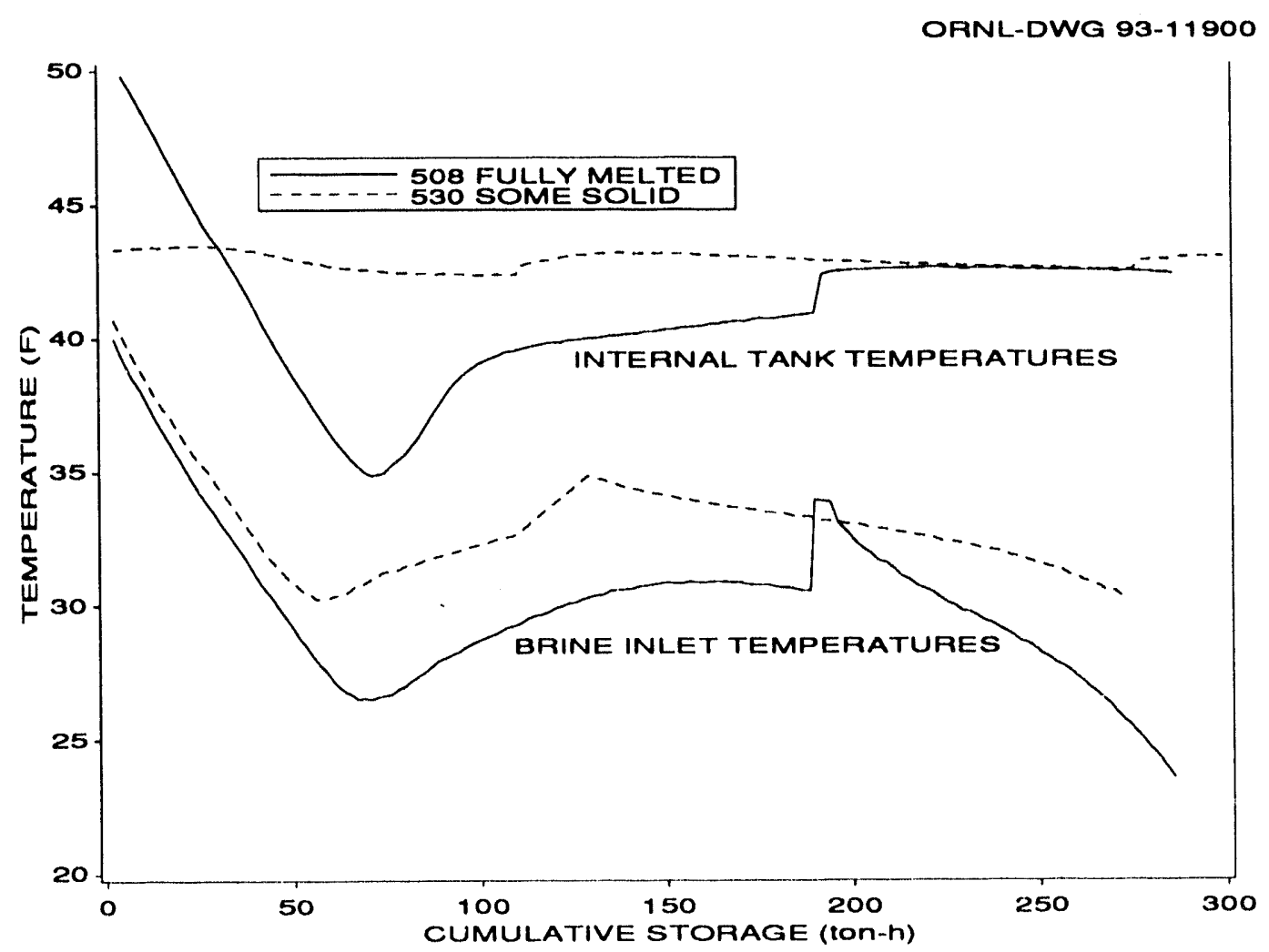

Fig. 7. Temperature profiles for tests 0508 and 0530 differ based on storage tank's initial conditions.

$\mathrm{NaOH}$ temperatures are very nearly constant throughout the test. The Transphase design includes a nucleating agent to reduce the subcooling. Indeed, another $\mathrm{NaOH} / \mathrm{H}_{2} \mathrm{O}$ phase diagram shows a subcooling curve for this concentration that drops to $\sim 26^{\circ} \mathrm{F}$, much lower than any internal tank temperatures measured during the tests. ${ }^{5}$

Capacity calculations were described in Sect. 4.2 and are based on an energy balance on the storage tank. At any given time, the capacity is the product of the brine mass flow rate and the brine temperature change in the storage tank. Figure 2 showed that the brine flow rate drops somewhat (for a constant pump setting) as the brine temperature drops. Figure 8 shows that the difference between the brine inlet and outlet also decreases slightly as the solid PCM builds up within the storage tank, even though the internal tank temperature remains constant. These factors combine to produce the capacity curves shown in Fig. 9. Overall, the capacity remains relatively steady throughout most of the charge cycle. This is most visible for those tests run at the higher rates, greater than 35 ton. Tests 


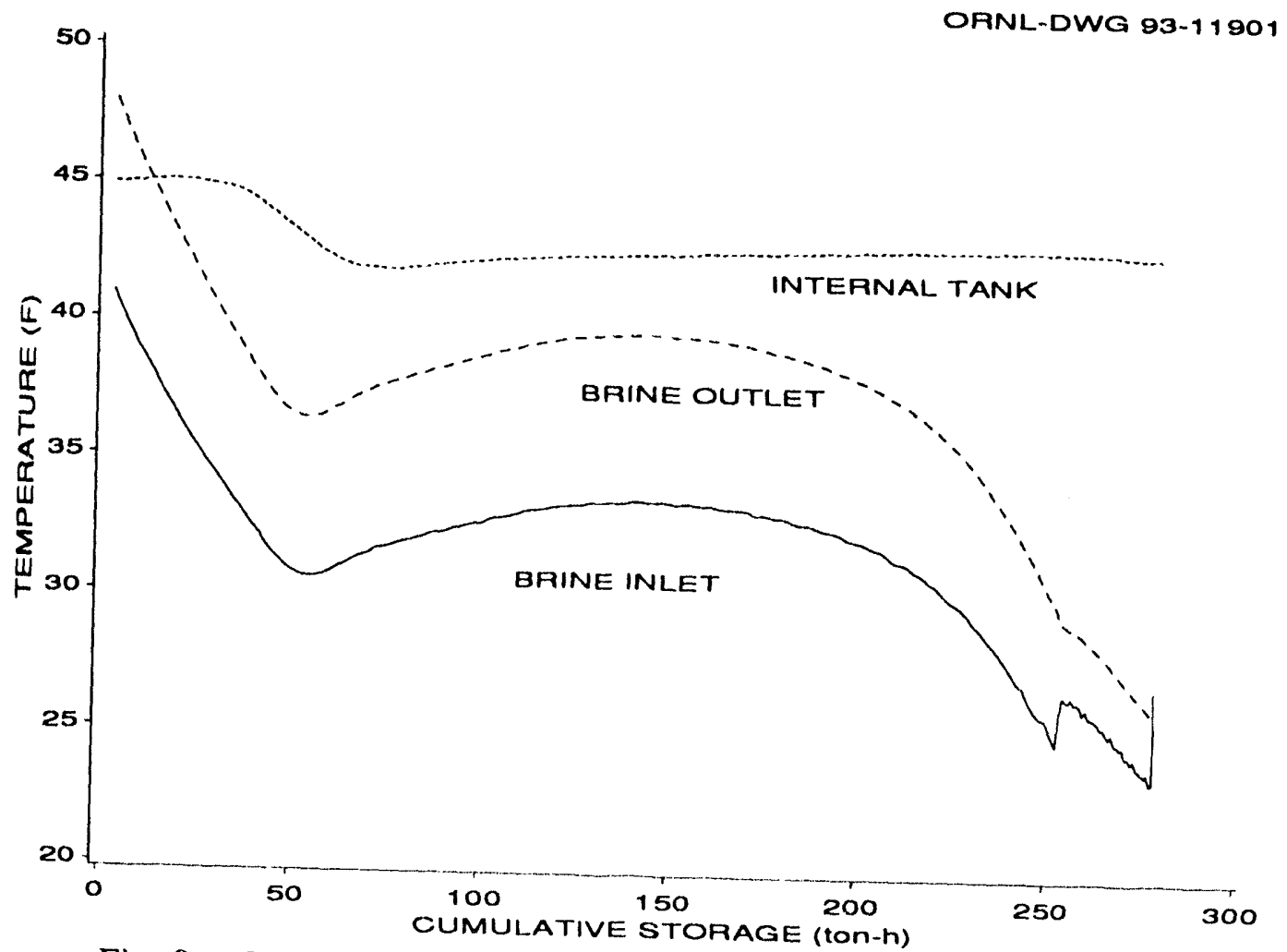

Fig. 8. Charge test 0606 began with some frozen eutectic in the tank and charged at a rate of $\sim 19$ ton.

in the 25 ton range show the more traditional curvature, expected as solid PCM begins to form and grows ever thicker on the tubular heat exchanger surface. Those tests that began from the partially frozen state show less variation in the early stages of the tests compared to those that began in the fully melted state. All tests at rates greater than 20 ton show the expected decrease in capacity near the end of the test, as the tank becomes fully charged. However, one test was run at a very slow rate of about 15 ton. This test never showed any decrease in charging rate, even though the test extended over a 4-day period. Later calculations estimated that the jacket heat gains for the uninsulated tank were very large and that this test probably never reached the fully charged state.

The brine flow rate is also an important parameter in determining the brine inlet temperature. Figure 10 shows the variation in brine inlet temperature for tests with the approximate charging rate of 21-23 tons and brine flows that vary from 50 to $93 \mathrm{gpm}$. All of these tests began with a fully melted tank. The ISTF evaporator froze at the lowest flow 


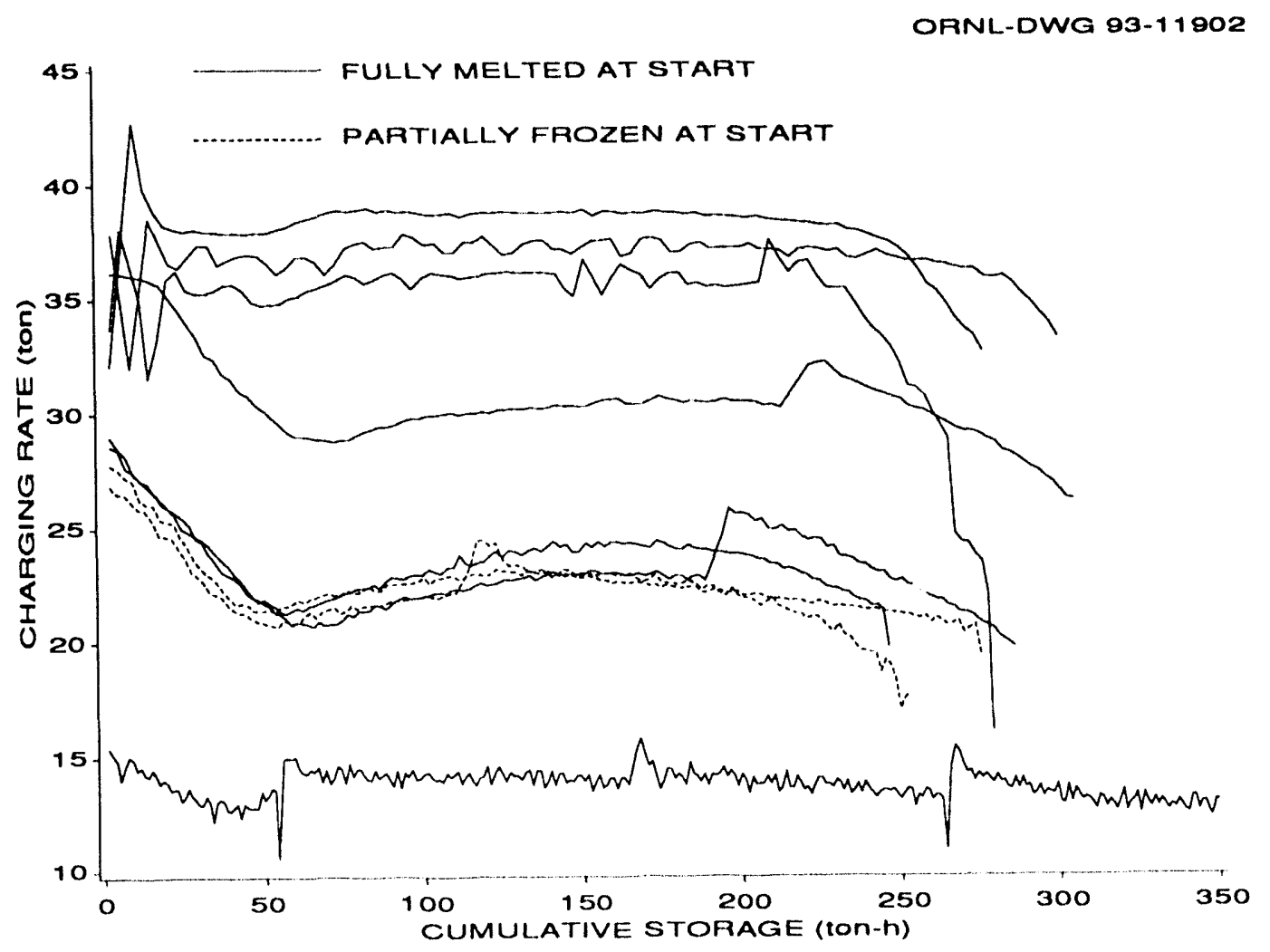

Fig. 9. Charging rate varies only slightly during course of nine freeze tests.

rate and that test had to be stopped before nucleation began in the storage tank. Figure 10 also shows the mean brine temperature in the storage tank, i.e. the average of the brine inlet and outlet temperatures. The difference between the brine inlet temperatures for the high and low flow tests is greater than the difference between the average brine temperatures. Theoretically, this average brine temperature should be strictly a function of capacity and the heat exchanger design, with the flow rate controlling the difference between the brine inlet and outlet temperatures.

\subsection{DISCHARGE PERFORMANCE}

The ISTF simulates a building load with a resistance heater. This portion of the test loop was designed to model a constant load while maintaining constant inlet and outlet temperatures to the load. This is accomplished by recirculating a portion of the brine from the heater outlet to the heater inlet, bypassing the storage tank, as is shown in Fig. 1. 


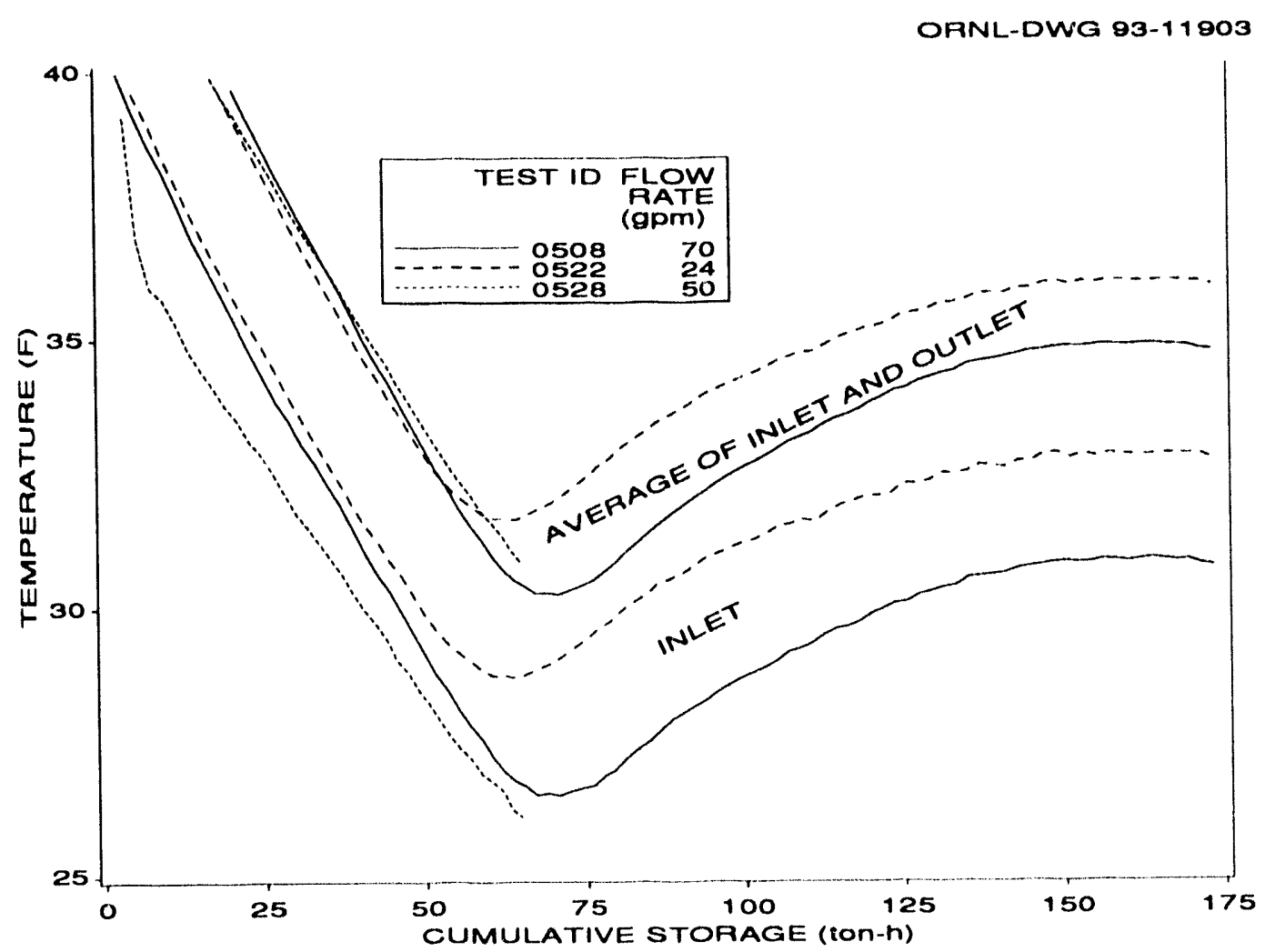

Fig. 10. Brine inlet and average temperatures for tests with charging rates from 21 to 23 ton.

During the course of the discharge test, the brine temperature leaving the storage tank gradually rises and this recirculation steadily decreases until the brine exiting the storage tank is at the desired heater inlet temperature. After that time, the desired heater outlet temperature is maintained by increasing the brine flow through the heater/storage tank loop. The test is considered completed when it is no longer possible to increase the brine flow and the heater outlet temperature exceeds the desired value. Also, tests were made with a constant flow through the storage tank to investigate whether this would increase the available cool storage capacity. For these tests, the brine flow rate and heater power were held constant, there was no brine recirculation, and the brine temperatures were uncontrolled. Also, one test was made with a constant brine flow and a variable discharge rate, maintaining the heater outlet (storage tank inlet) temperature below a selected maximum value. All the discharge tests are summarized in Table 4. 
Table 4. Transphase discharge test summary

\begin{tabular}{|c|c|c|c|c|c|c|c|c|c|c|}
\hline $\begin{array}{l}\text { Test } \\
\text { ID }\end{array}$ & $\begin{array}{c}\text { Test } \\
\text { duration } \\
\text { (h) }\end{array}$ & $\begin{array}{l}\text { Number } \\
\text { of open } \\
\text { circuits }\end{array}$ & $\begin{array}{c}\text { Control } \\
\text { strategy }^{\mathbf{a}}\end{array}$ & $\begin{array}{c}\text { Average } \\
\text { discharge } \\
\text { rate } \\
\text { (ton) }\end{array}$ & $\begin{array}{c}\text { Cumulative } \\
\text { discharge } \\
\text { energy } \\
\text { (T-h) }\end{array}$ & $\begin{array}{c}\text { Cumulative } \\
\text { discharge } \\
\text { energy } \\
\leq 50^{\circ} \mathrm{F} \\
(\mathrm{T}-\mathrm{h})\end{array}$ & $\begin{array}{c}\text { Average } \\
\text { pump } \\
\text { power } \\
(\mathrm{kW})\end{array}$ & $\begin{array}{c}\text { Average } \\
\text { flow to } \\
\text { storage } \\
\text { tank } \\
\text { (gpm) }\end{array}$ & $\begin{array}{c}\text { Average } \\
\text { temperature } \\
\text { leaving } \\
\text { storage tank } \\
\quad\left({ }^{\circ} \mathrm{F}\right)\end{array}$ & $\begin{array}{c}\text { Average } \\
\text { temperature } \\
\text { into } \\
\text { storage tank } \\
\left({ }^{\circ} \mathrm{F}\right) \\
\end{array}$ \\
\hline 0506 & 5.8 & 8 & $\begin{array}{l}\text { Constant } \\
\text { flow }\end{array}$ & 32.7 & $194^{c}$ & $86^{c}$ & 3.0 & 88 & 53.7 & 62.8 \\
\hline 0523 & 5.2 & 7 & $60^{\circ} \mathrm{F}$ in & 35.1 & 185 & NA & 1.8 & 59 & 44.8 & 60.1 \\
\hline 0604 & 6.2 & 8 & $\begin{array}{l}\text { Constant } \\
\text { flow }\end{array}$ & 35.4 & 223 & 218 & 4.9 & 107 & 44.6 & 52.8 \\
\hline 0610 & 7.0 & 7 & $60^{\circ} \mathrm{F}$ in & 27.9 & $199^{d}$ & $185^{d}$ & 1.5 & 53 & 46.0 & 59.6 \\
\hline 0614 & 6.7 & $9-8^{c}$ & $\begin{array}{l}\text { Constant } \\
\text { flow }\end{array}$ & 34.2 & 231 & 228 & 4.0 & 100 & 44.4 & 52.9 \\
\hline 0619 & 11.6 & 8 & $60^{\circ} \mathrm{F}$ in & 21.9 & 254 & 219 & 1.0 & 44 & 46.8 & 60.0 \\
\hline 0625 & 10.8 & 8 & $\begin{array}{l}\text { Variable } \\
\text { power }\end{array}$ & 27.0 & 292 & 229 & 4.3 & 102 & 48.6 & 55.2 \\
\hline 0627 & 11.1 & 8 & $\begin{array}{l}\text { Constant } \\
\text { flow }\end{array}$ & 21.9 & 249 & 215 & 4.9 & 105 & 45.1 & 50.3 \\
\hline
\end{tabular}

- 'Constant flow' tests maintained a constant brine flow rate to the storage tank. ' $60^{\circ} \mathrm{F}$ in' tests used the heater bypass to maintain a constant temperature of $60^{\circ} \mathrm{F}$ entering the ice tank.

b Discharge energy produced with a storage tank outlet temperature $\leq 50^{\circ} \mathrm{F}$.

c Five days elapsed between end of charge and start of discharge test. Initial storage capacity diminished by substantial tank wall heat gains over this period.

d Two days elapsed between end of charge and start of discharge test.

- One circuit was closed during the test. 
As mentioned in Sect. 4.3, the discharge capacity was measured at both the heater and the storage tank. The measurement at the heater should be slightly less than the measurement at the storage tank because of heat added to the brine by the circulation pumps. Therefore, the total discharge energy measured at the storage tank was compared to the sum of the total measured at the heater plus the pump energy. These two values matched within $3 \%$ for all the tests, good agreement considering that the flow meters and temperature measurements are completely independent. All capacity data presented in this section are based on the temperature difference and brine flow rate at the storage tank.

The heat transfer resistance between the brine flowing through the storage tank and the frozen $\mathrm{NaOH}$ consists of three components: the convective heat transfer at the inner wall of the heat exchanger tubing, the conduction through the thickness of the tube wall, and the conduction through the melted $\mathrm{NaOH}$ surrounding the tube. The second term is constant and the largest of the three. The convective transfer at the inner wall of the tube varies with the brine flow rate. At the rat, tested at the ISTF, from -50 to $100 \mathrm{gpm}$, the flow is in the transition region between laminar and turbulent flow. For this reason, the convective heat transfer coefficient is not precisely defined, but will range from 5 to $30 \%$ of the constant resistance posed by the tube wall thickness. This convective resistance is a constant value for those discharge tests run at a constant brine flow rate but will gradually decrease for those tests with controlled heater inlet and outlet temperatures as the brine flow rate to the tank increases near the end of the discharge cycle. The maximum decrease in the convective heat resistance would occur when the flow changes from laminar to turbulent and would then account for a maximum decrease of $15 \%$ in the temperature difference between the brine and the solid $\mathrm{NaOH}$. The resistance due to the melted $\mathrm{NaOH}$ surrounding the tube will increase throughout the discharge cycle, rising to a level almost equal to that of the tube wall thickness near the end of the discharge. This growing resistance can be seen in Figs. 11 and 12, where the frozen $\mathrm{NaOH}$ supply maintains a nearly constant temperature but the brine temperature leaving the tank rises at the end of the discharge cycle. The shape of the brine temperature curves is related to the logarithmic growth (due 


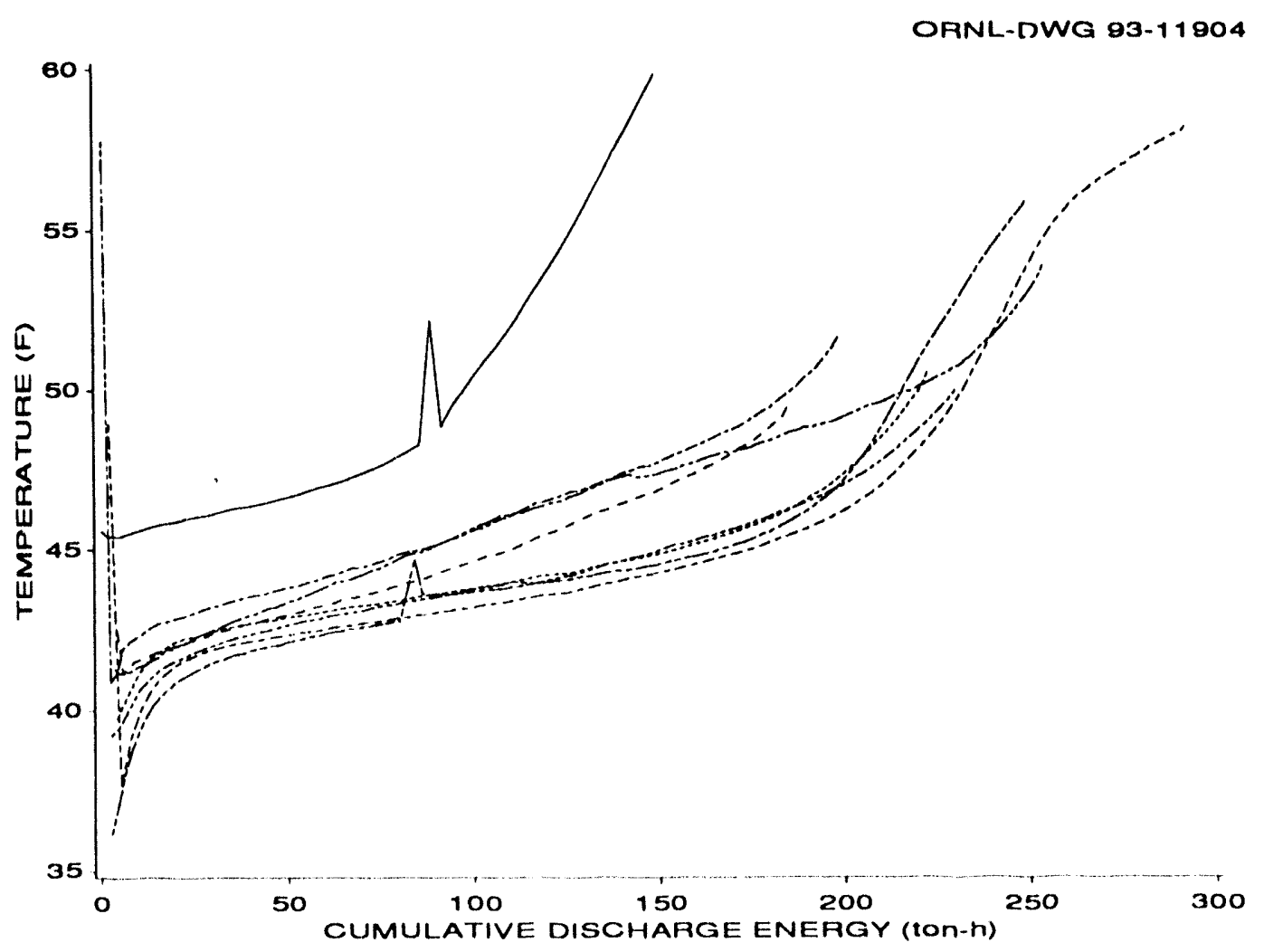

Fig. 11. Brine temperature at storage tank outlet during melt tests.

to the cylindrical geometry) of this liquid heat transfer resistance, culminating in a $50 \%$ increase in the temperature difference between the brine and the frozen $\mathrm{NaOH}$.

Figure 11 shows the discharge temperature profiles vs the cumulative discharge energy for all the discharge tests listed in Table 4. This figure demonstrates that the tank outlet temperature holds a relatively constant value throughout much of the discharge cycle. (The one test showing much higher temperatures is discussed later in this section.) The increase in temperature near the end of each test signals the end of the available latent storage. Figure 12 shows the temperature measured within the $\mathrm{NaOH}$, at a point about 21 in. below the surface and between two sections of heat exchanger tubes. Examination of these two figures shows that total latent storage and total available latent storage are different quantities depending on the maximum useable brine outlet temperature. The $\mathrm{NaOH}$ temperature is relatively constant, indicating that a significant portion of the $\mathrm{NaOH}$ is still frozen for $-50 \mathrm{~T}-\mathrm{h}$ after the tank outlet temperature has begun to rise rapidly. 


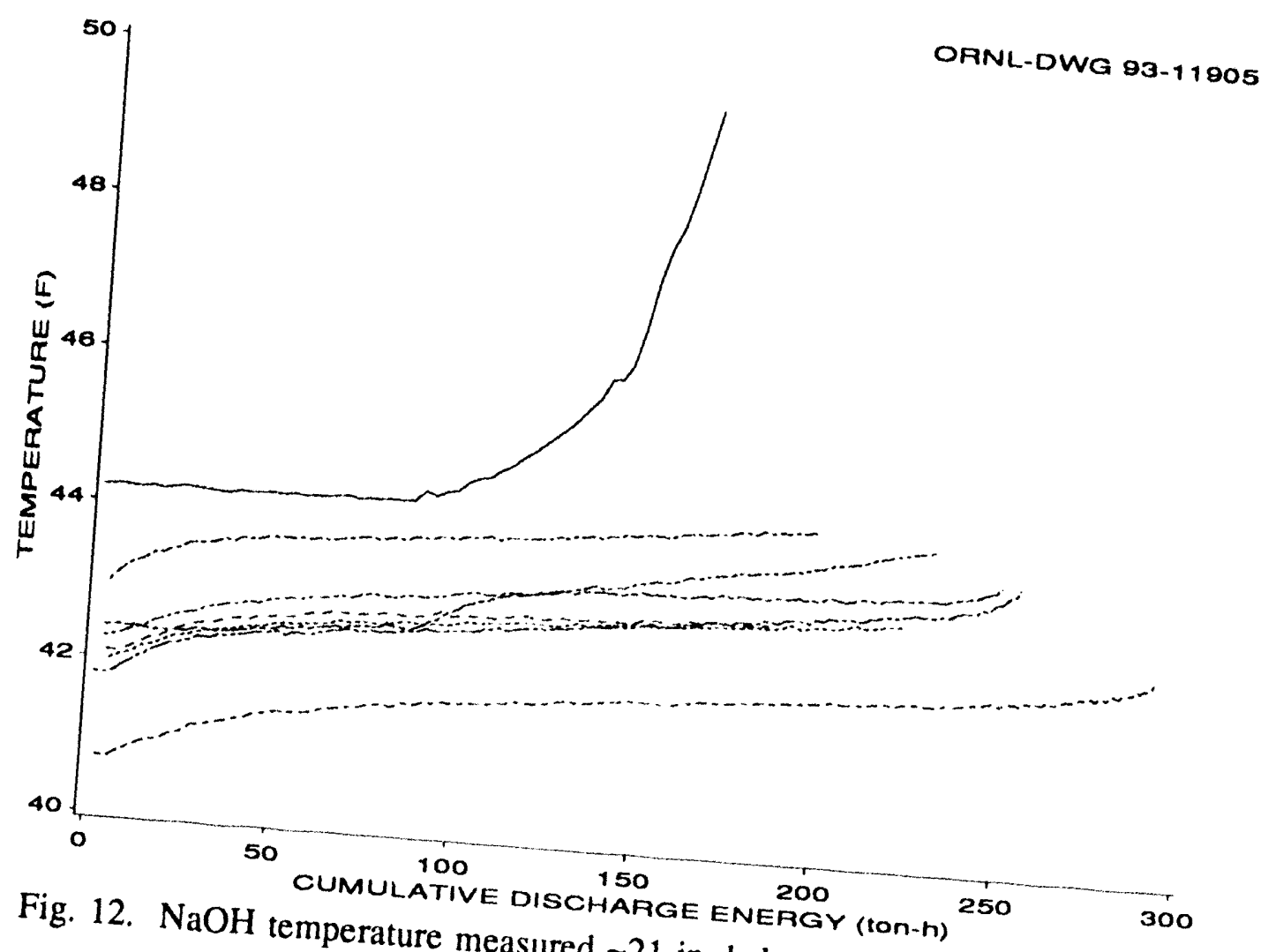

Fig. 12. NaOH temperature measured

acity on brine outlet temperature is shown in Table do the cumulative temperatures $<50^{\circ} \mathrm{F}$. For other cool storage units, we with the discharge parameters of acceptable outlet the Transphase unit, the very large and because there was no always comparable because the shell heat gains were Therefore, slight differences in charging condito measure the latent storage inventory. conditions or in the amount of elapsed time cle had an important effect on the total amount of Fig. 11 that started with initial temple this initial variability is shown by the one test temperature. This test represents a case beginning of the discharge test. Although the the tank was not fully charged at the of total available capacity, the data can still constraints prevent a meaningful prediction 
available capacity to the acceptable outlet temperature and discharge rate. This analysis showed, with high confidence levels, that $\sim 12$ additional $T-h$ are available for each increase of $1^{\circ} \mathrm{F}$ in the acceptable outlet temperature. Also, the capacity is increased by $\sim 10 \mathrm{~T}-\mathrm{h}$ for each increase of $1 \mathrm{~h}$ in the discharge time, i.e. a decrease in the discharge rate increases the total available stored energy.

Figures 13 and 14 show 4 tests made with constant discharge capacities of 21 or 35 tons. Figure 13 displays the difference in control strategies among the tests. Two tests were made with constant brine flow rates to the storage tank with no attempt to control the temperatures anywhere in the loop. The other two tests used the bypass control shown in Fig. 1 to maintain the heater inlet temperature at $45^{\circ} \mathrm{F}$ and the heater outlet temperature at $60^{\circ} \mathrm{F}$. After the brine temperature leaving the tank exceeded $45^{\circ} \mathrm{F}$, these two tests were continued until the heater outlet temperature of $60^{\circ} \mathrm{F}$ could no longer be maintained. Figure 14 shows the temperature profiles of the brine leaving the storage tank for these same four

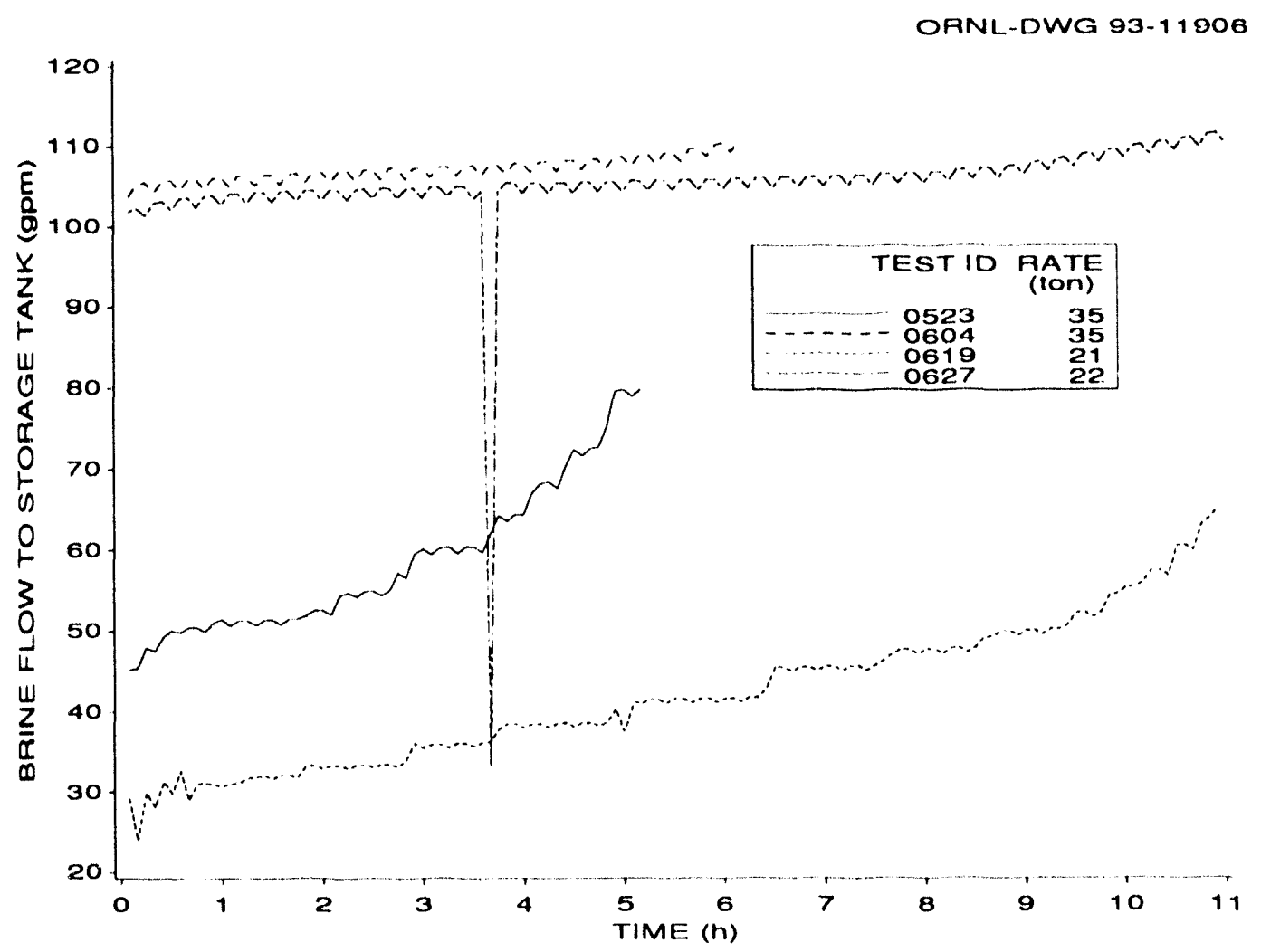

Fig. 13. Brine flow rates for two different control strategies during melt tests. 


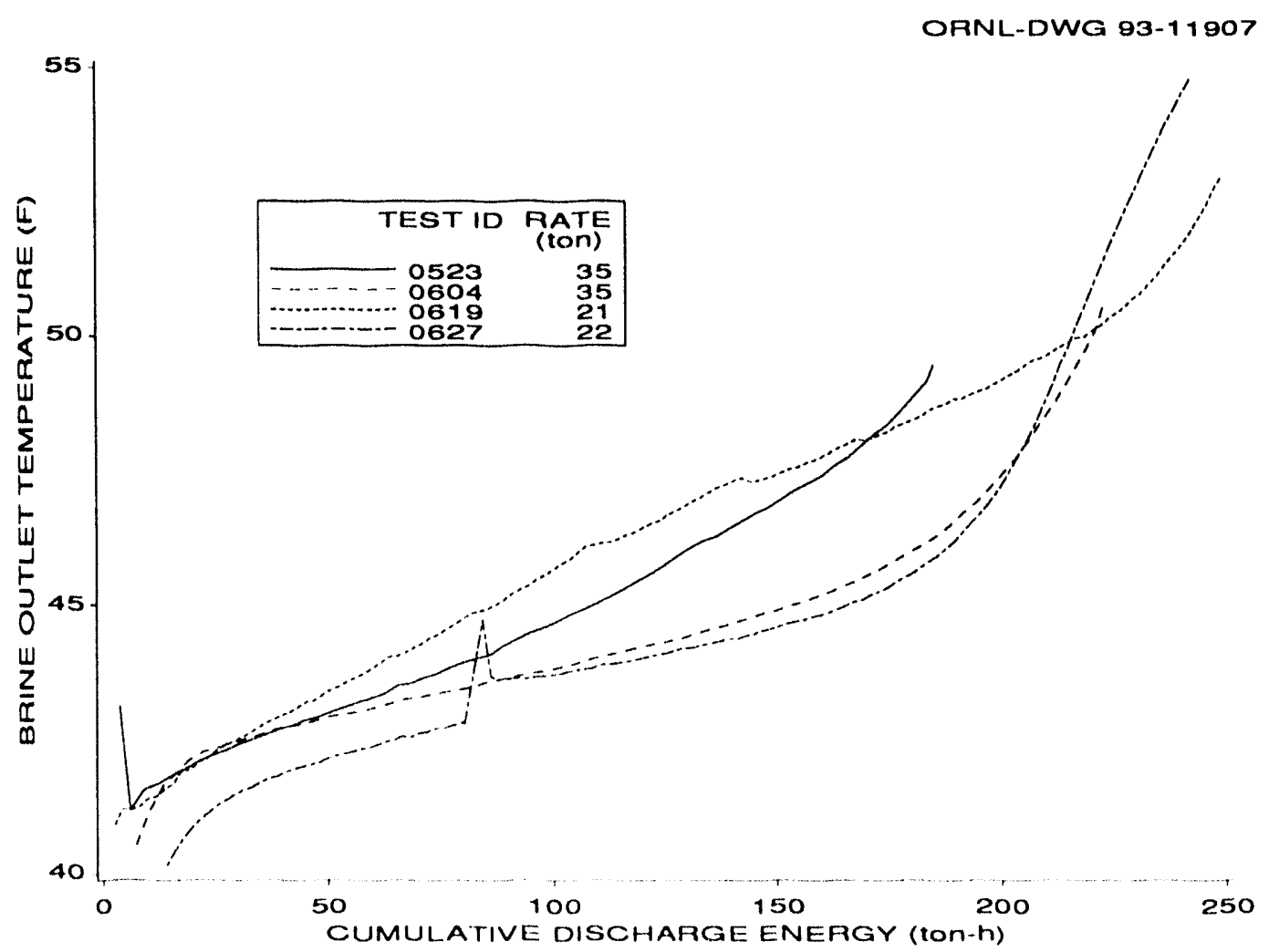

Fig. 14. Storage tank outlet temperature for two different control strategies during melt tests.

tests. As expected, the higher brine flow rates produce lower brine temperatures for comparable discharge rates because the product of the brine mass flow and temperature change must be the same (see Eq. 7). Those tests with temperature controls (0523 and 0619), and therefore growing brine flow rates, show a markedly different temperature profile than those for the constant brine flow rate tests (0604 and 0627). As discussed earlier, with a constant brine flow rate, the temperature of the brine leaving the tank will only vary with the logarithmic growth of the fluid resistance surrounding the heat exchanger tubes. Therefore tests 0604 and 0627 show an initially flatter profile with a sharply increasing temperature near the end of the test. However, with variable brine flow, the convective heat transfer within the tube is increasing as the heat transfer through the melted $\mathrm{NaOH}$ is decreasing, producing the more linear temperature profile shown for tests 0523 and 0619 .

Another test was made to examine the reduction in capacity that would occur for a discharge in which the tank inlet (or heater outlet) temperature was held constant. The 
discharge rate was held constant at 35 tons (the maximum available at the ISTF) until the heater outlet temperature exceeded $60^{\circ} \mathrm{F}$, after which the heater power was reduced as necessary to maintain this temperature. Figure 15 shows the storage tank outlet temperature, the internal $\mathrm{NaOH}$ temperature, and the discharge rate for this test. The drop off in discharge rate after $7 \mathrm{~h}$, or $\sim 250 \mathrm{~T}$-h was quite sharp. However, the internal tank temperature remains almost constant throughout the test, indicating the presence of remaining latent storage. Again, the growing volume of melted $\mathrm{NaOH}$ provides quickly growing heat transfer resistance near the end of the discharge cycle, limiting the availability of the stored energy.

Three tests were made under the same control strategy $\left(45^{\circ} \mathrm{F}\right.$ into the heater and $60^{\circ} \mathrm{F}$ out of the heater) at three different discharge rates of 35,28 , and 21 tons. The storage tank outlet temperatures for these tests are shown in Figs. 16 and 17. Figure 16 shows that

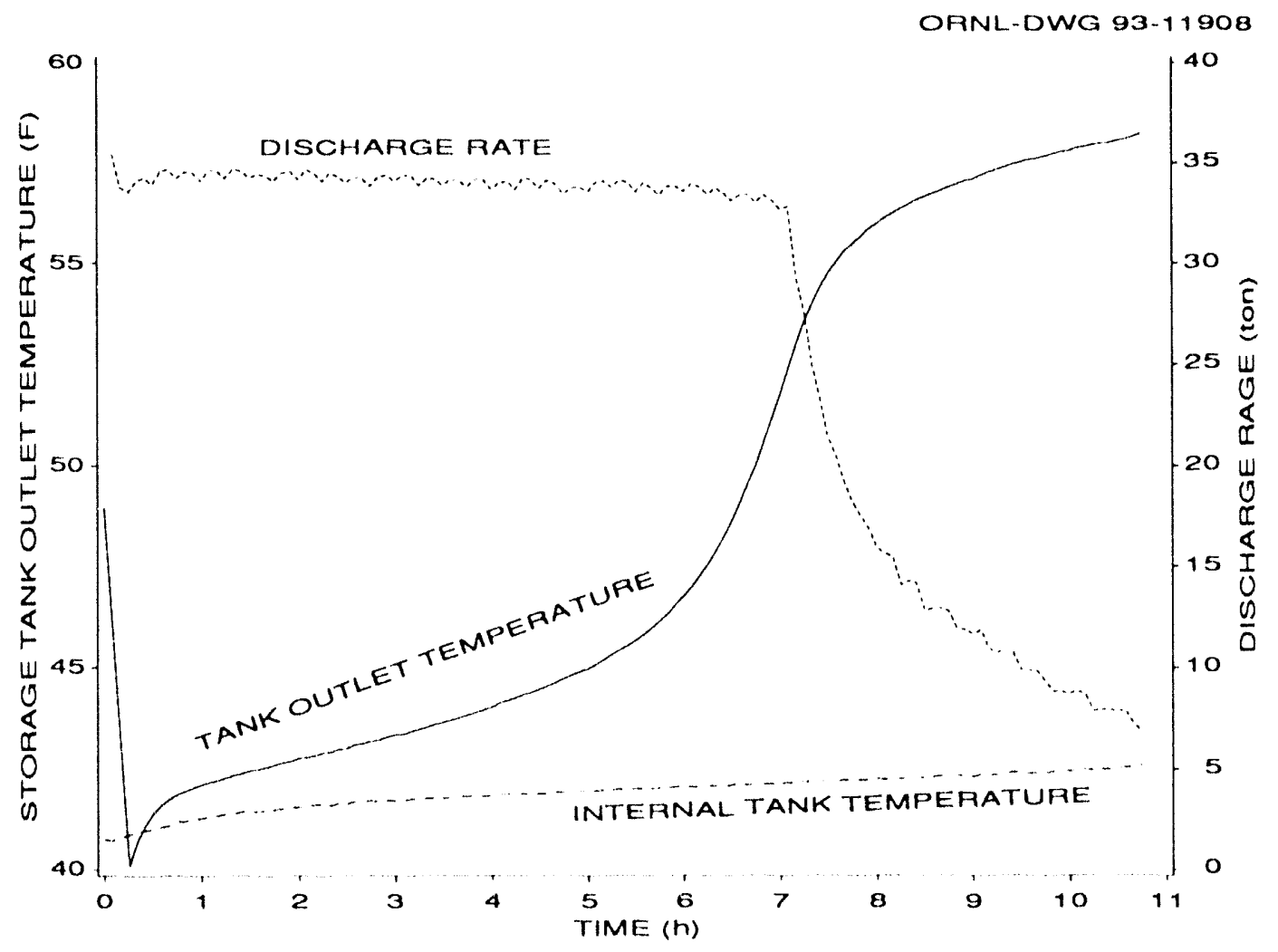

Fig. 15. Variable discharge rate during melt test 0625 . 


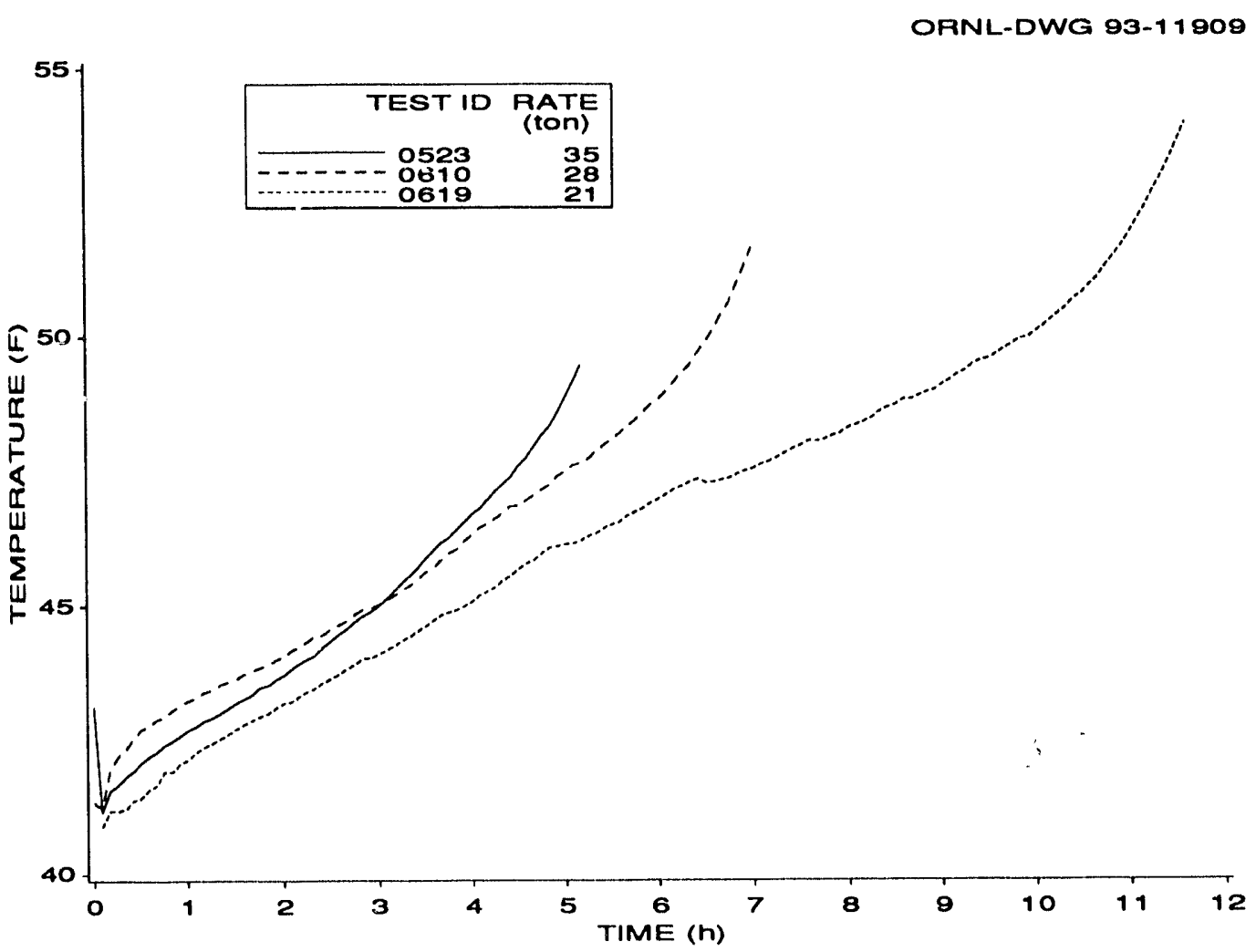

Fig. 16. Storage tank outlet temperatures for controlled tank inlet temperature of $60^{\circ} \mathrm{F}$ with constant discharge rates.

the slower discharge rate provides slightly lower outlet temperatures, as expected, for a longer period of time. However, when these same temperature profiles are plotted against the cumulative discharge energy in Fig. 17, they are very nearly identical. It may be possible, therefore, to characterize the tank's inventory as a function of brine outlet temperature for a given tank inlet temperature.

Power requirements during discharge include brine pumping power. The pumping power varies with the brine flow rate and ranged from 1 to $5 \mathrm{~kW}$. This accounted for an approximate heat input to the brine of between 2 to $13 \mathrm{~T}-\mathrm{h}$ over the course of the discharge cycle, assuming that all the pump power is converted to heat in the brine. Those tests made with a constant brine flow rate used from 2 to 3 times as much pumping power as those made with controlled temperatures at the heater inlet and outlet. 


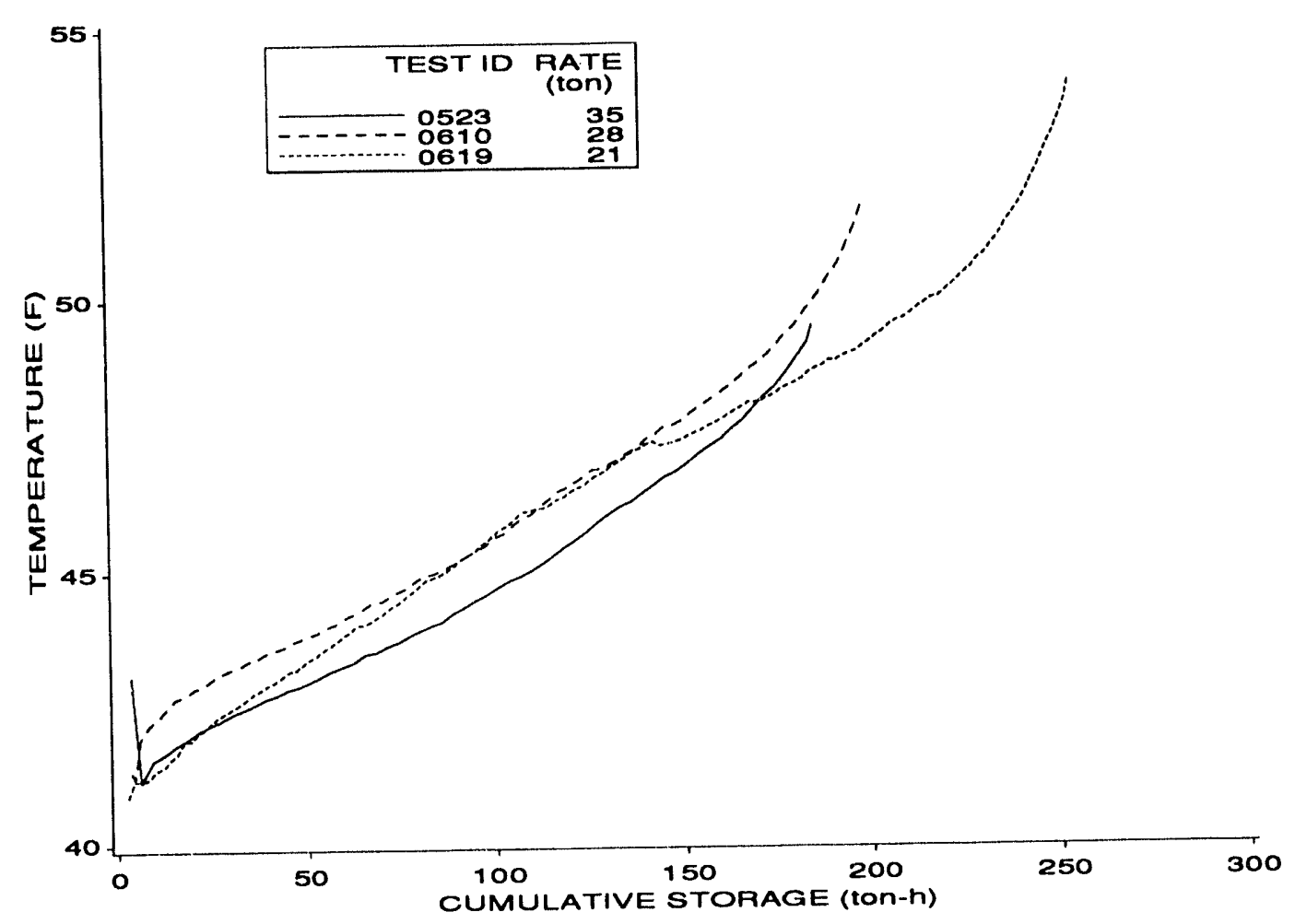

Fig. 17. Storage tank outlet temperatures for controlled tank inlet temperature of $60^{\circ} \mathrm{F}$ with constant discharge rates.

\subsection{STANDBY HEAT GAINS}

The Transphase prototype unit was not insulated, although the double wall construction provided a small amount of heat transfer resistance. Anytime the tank contents were cold, there was visible condensation on the outer plastic wall, usually running and dripping down the side of the tank. At one point, so much condensation had accumulated in the dike surrounding the tank that it was necessary to add chlorine to this diked area to inhibit the growth of odoriferous water creatures. The ambient temperature in the test area remained between 65 and $85^{\circ} \mathrm{F}$, the humidity was usually high, and there was no direct sunlight upon the tank.

Without an inventory meter, it was not possible to directly measure the jacket heat gains. However, an estimate was made using the well defined parameters of tank surface area, surface temperature, and ambient temperature. The appropriate convective heat 
transfer coefficient, for condensation under natural convection conditions, is not as easy to pin down. Various handbooks recommend values ranging from 0.59 to $1.65 \mathrm{Btu} / \mathrm{h}-\mathrm{ft}^{2}-{ }^{\circ} \mathrm{F}$, giving heat gain rates from 0.7 to 3 tons. ${ }^{7,8}$ These produce daily heat gain estimates ranging from 18 to $70 \mathrm{~T}$-h/day, for a tank in a cold $\left(-40^{\circ} \mathrm{F}\right)$ state. One charge test, 0425 , was run at a very slow rate of about 15 ton. This test never showed any decrease in charging rate, even though the test extended over a 4-day period and the refrigeration system removed $-355 \mathrm{~T}-\mathrm{h}$ of heat from the tank (see Fig. 9). This steady charging rate indicates that the tank was never fully charged. Since most charge tests showed some decrease in charging rate at $\sim 200 \mathrm{~T}-\mathrm{h}$, one could estimate that at least $150 \mathrm{~T}-\mathrm{h}$ of heat had been added to the storage tank through the shell. The shell heat gain rate would then be at least $-40 \mathrm{~T}-\mathrm{h} / \mathrm{day}$ and could be greater. If the shell heat gains occurred at a rate of $70 \mathrm{~T}$-h/day, it would have taken about 6 days to fully charge the system (with a charging cycle of $15 \mathrm{~h} /$ day at a rate of 15 ton) before any decrease in the cooling capacity would have been visible. 


\section{CONCLUSIONS AND RECOMMENDATIONS}

The cool storage unit tested was Transphase, Inc.'s first full scale prototype of a new design based on a $41^{\circ} \mathrm{F}$ eutectic. The design is comprised of a horizontal cylinder filled with eutectic material and containing an internal plastic heat exchanger used to circulate a brine mixture through the storage medium. This prototype was tested to determine both its thermal and operational characteristics. During the ISTF tests, the thermal behavior was measured and met reasonable expectations. The eutectic froze and melted very near the predicted temperature of $41^{\circ} \mathrm{F}$, with only a small amount of subcooling when freezing from a fully-melted state. Compared to available subcooling curves for this material, the design effectively reduced this unwanted phenomenon. Although the lack of insulation makes any quantitative determination of total storage capacity imprecise, the unit was able to provide $-250 \mathrm{~T}-\mathrm{h}$ of cooling under a variety of test conditions.

The prototype unit exhibited several operational problems that should be eliminated from future models. First, the heat exchanger construction should be made leak-free. Second, some means of removing the air from the heat exchanger coils should be implemented, perhaps by reorienting the coils or the tank to permit the necessary venting. Third, future development efforts should include some form of inventory measurement. Fourth, the bottom drain plug should be removed from the tank design to improve the overall safety. Future installations should be insulated.

One of the most important issues in this prototype test was that of eutectic stability. This issue warrants further study. Although the trends towa d stratification noted in this work are slight, they were measurable and would impact the long term thermal qualities of the eutectic. Unfortunately, the confounding effect of the brine leakage into the storage tank can't be separated from the stratification effects under observation, leaving this issue open to debate. 


\section{REFERENCES}

1. T. K. Stovall and J. J. Tomlinson, Commercial Cool Storage Laboratory Test Procedure, ORNL/TM-11511, Martin Marietta Energy Systems, Inc., Oak Ridge Natl. Lab., May 1990.

2. G. T. Kartsounes and R. A. Erth, "Computer Calculation of the Thermodynamic Properties of Refrigerants 12, 22, and 502," ASHRAE paper No. 2200, presented at ASHRAE Annual Meeting, Washington D.C., August 22-25, 1971.

3. UCARTHERM Heat Transfer Fluid, Union Carbide Corporation, Industrial Chemicals Division, Danbury, Connecticut, 1986.

4. Caustic Soda Handbook, VMC-3395, Rev. 3/89, Vulcan Chemicals, Vulcan Materials Company, Birmingham, Alabama, 1989

5. A. Standen, Executive Editor, Kirk-Othmer ENCYCLOPEDIA OF CHEMICAL TECHNOLOGY, $2^{\text {nd }}$ edition, Vol 1, Interscience Publishers, Division of John Wiley \& Sons, Inc., New York, 1963, pp. 740-758.

6. Electric Power Research Institute, Commercial Cool Storage Design Guide, EM3981, Palo Alto, California, May 1985.

7. T. Baumeister, Ed., Marks' Standard Handbook for Mechanical Engineers, $8^{\text {th }}$ Ed., McGraw-Hill Book Company, New York, New York, 1978

8. E. Stamper, Ed., Handbook of Air Conditioning, Heating, and Ventilating, $3^{\text {rd }}$ Ed., Industrial Press, Inc., New York, New York, 1979 


\section{Appendix A}

\section{ISTF INSTRUMENTATION}

\section{A.1 DATA ACQUISITION AND CONTROL}

A data acquisition system and computer are used to control the thermal loading rate, the brine and refrigerant circulation pump speeds, recirculation valve positions, and the condensation temperature and to collect the data from system instrumentation. The computer allows short sampling times of the instrumentation to provide data for detailed analysis and feedback during transient system operation. Direct controls, outside of the data acquisition/computer system, are available for compressor loading, booster pump operation, and auxiliary portions of the test facility.

\section{A.2 TEMPERATURE MEASUREMENTS}

Refrigerant temperature measurements are made by RTDs bonded to the outside of the copper pipes. These RTDs were calibrated by the manufacturer to $0.3^{\circ} \mathrm{F}$. After installation, the recorded refrigerant temperatures were compared to the expected thermodynamic states for the corresponding pressure measurements. Water and brine temperature measurements are made by RTDs inserted into the PVC pipes. These RTDs are calibrated to $\pm 0.2^{\circ} \mathrm{F}$ and are checked against an ice bath periodically. The RTDs were also checked against each other under conditions where an unloaded heat exchanger, for example, would be expected to show the same inlet and outlet temperature.

\section{A.3 FLOW MEASUREMENTS}

Vortex-shedding flowmeters are used to measure the condenser cooling water flow, the water/brine flow to the heater, the water/brine flow to the storage tank, and the gaseous refrigerant flow to the condenser. The vortex-shedding refrigerant flowmeter imposes a pressure drop of -0.5 psia. These flowmeters are accurate to $\pm 0.8 \%$ of the reading for liquid flows and $\pm 1.5 \%$ of the reading for gaseous flows. The flowmeters used to measure 
water and brine volumetric flow were checked after installation by running water through the lines into a 55-gal. drum placed on a scale.

The Coriolis mass flowmeters used to measure liquid refrigerant mass flows to the lowpressure receiver, the storage tank, and the thermal expansion valves were calibrated by the manufacturer to $\pm 0.4 \%$ of full scale, which is $1000 \mathrm{lb} / \mathrm{min}$. A sight glass is positioned to provide a visual confirmation of single-phase flow downstream of the meter. These Coriolis flowmeters are very difficult to calibrate after installation because of the closed nature of the refrigerant system. However, the volumetric flow through one of the vortex-shedding flowmeters can be compared to the mass flow through one of these Coriolis meters. Also, energy balances on the condenser, low-pressure receiver, chiller/evaporator, and storage tank can be used to assess the continued accuracy of these devices.

\section{A.4 PRESSURE MEASUREMENTS}

Refrigerant pressure measurements are made with pressure transducers to allow the electronic recording of the values. The accuracy of these absolute pressure readings is rated at $+10.11 \%$ of full scale. However, the calibration certificates supplied with each transducer show accuracies of $\pm 0.004 \%$ or better. Also, the transducer calibration was rechecked after installation and periodically thereafter using laboratory calibration equipment. The pressure transducers located in the high-pressure portion of the loop, that is, between the compressor discharge and the expansion valve, are rated for 0 to 5()$)$ psia. All others are rated for 0 to 250 psia. During testing, the pressure measurements are periodically compared to other measurements within the loop and to the expected refrigerant properties.

A differential pressure meter can be used to measure the change in tank water depth during charging. The meter measures from 0 to 10 in. of water with an accuracy of $\pm 0.5 \%$ of full range output (i.e., \pm 0.05 in. of water). This instrument was not used during the Transphase tests. 


\section{A.5 ELECTRICAL MEASUREMENTS}

Electrical measurements for the compressor power (rated at 40 and $75 \mathrm{hp}$ ), circulating pump(s) power (from 2 to $5 \mathrm{hp}$ ), agitation air compressor power (1/2 hp), and heater power ( 0 to $135 \mathrm{~kW})$ are measured by watt/watt-hour transducers. The watt-hour measurements are accurate to $\pm[0.2 \%$ of the reading $+0.01 \%$ of the rated output)/(power factor)]. The watt-hour meters for the compressors were checked by measuring the voltage and current on each of three phases. The watt-hour meter for the heater was checked by comparison to the heat absorbed by the water as measured by the flow and temperature change. The accuracy of this heater's watt-hour meter is poor because of the semiconductor-controlled rectifier (SCR), or phase-angle power controller, used to vary the heater power. Heater energy use measurements are therefore based on the fluid flow rate and temperature change, although the power consumption is reco. led as an additional check. 
ORNL/TM-12499

Dist. Category UC-202

\section{Internal Distribution}

1. T. D. Anderson

2. V. D. Baxter

3. S. H. Buechler

4. R. S. Carlsmith

5. W. G. Craddick

6. P. D. Fairchild

7. D. J. Fraysier

8. W. Fulkerson

9. R. B. Honea

10. J. E. Jones Jr.

11. L. Jung

12. W. A. Miller

13. W. R. Mixon

14. M. Olszewski
15. A. C. Schaffhauser

16. M. Siman-Tov

17-26. T. K. Stovall

27. J. J. Tomlinson

28. C. D. West

29. G. L. Yoder

30. ORNL Patent Section

31. Central Research Library

32. Document Reference Section

33-34. Laboratory Records Department

35. Laboratory Records (RC)

\section{External Distribution}

36. Doug Ames, Transphase, Inc. 15572 Commuter Lane, Huntington Beach, California 92649

37. John Stephen Anderpont, Chicago Bridge \& Iron Company, 800 Jorie Boulevard, Oak Brook, IL 60522-7001

38. John Bruce, Transphase, Inc. 15572 Commuter Lane, Huntington Beach, California 92649

39. Debra L. Catanese, P.E., Pennsylvania Electric Company, 311 Industrial Park Rd., Johnstown, PA 15904

40. Tom Carter, Baltimore Aircoil Company, P.O. Box 7322, Baltimore, MD 21227

41. Russ Eaton, Director, Advanced Utility Concepts Division, U.S. Department of Energy, Forrestal Building, CE-142, 1000 Independence Avenue, Washington, DC 20585

42. Freemon Ford, FAFCO, Inc., 2690 Middlefield Road, Redwood City, California 940633455

43. Imre Gyuk, Office of Energy Storage and Distribution, U.S. Department of Energy, Forrestal Building, CE-32, 1000 Independence Avenue, Washington, DC 20585

44. Landis Kannberg, Battelle Pacific Northwest Laboratories, P.O. Box 999, Battelle Boulevard, Richland, WA 99352

45. Don Kemp, Turbo Refrigerating Company, 1815 Shady Oaks Drive, P.O. Box 396, Denton, TX 76202

46. K. W. Klunder, Director, Office of Energy Management, Department of Energy, CE-14, Forrestal Building, 1000 Independence Avenue, Washington, DC 20585 
47-96. Dave Knebel, Director of Research, Thermal Storage Applications Research Center, University of Wisconsin-Madison, 150 E. Gilman Street, Suite 1200, Madison, WI 537031493

97. George Manthey, DOE, Oak Ridge Operations, Oak Ridge, TN 37831

98. Robert P. Miller, Baltimore Aircoil Company, P.O. Box 7322, Baltimore, MD 21227

99. Tony Min, Mechanical Engineering Department, North Carolina Agricultural and Technical State University, Greensboro, NC 27411

100. Victor A. Needham III, Marketing Programs Director, Cincinnati Gas \& Electric Company, P. O. Box 960, Cincinnati, Ohio, 45201.

101. Dave Pellish, U.S. Department of Energy, Forrestal Building, MS CE-332, Room 5H-79, 1000 Independence Avenue, Washington, DC 20585

102. Veronika A. Rabl, Electric Power Research Institute, 3412 Hillview Avenue, P.O. Box 10412, Palo Alto, CA 94303

103. Eberhart Reimers, Advanced Utility Concepts Division, U.S. Department of Energy, Forrestal Building, CE-142, 1000 Independence Avenue, Washington, DC 20585

104. Richard Rhodes, FAFCO, Inc., 2690 Middlefield Road, Redwood City, California 940633455

105. Marwan Saliba, Energy Engineering Institute, Dept. of Mechanical Engineering, San Diego State University, San Diego, CA 92182-(0191

106. Brian Silvetti, Calmac Manufacturing Corporation, Box 710, 150 South Van Brunt Street, Englewood, NJ 07631

107. Robert L. San Martin, Deputy Assistant Secretary, Office of Utility Technology, Department of Energy, CE-10, 6C-(026/Forrestal Bldg., 1(X)(X) Independence Avenue, Washington, DC 20585

108. Chang W. Sohn, U.S. Army Corps of Engineers, P.O. Box 4(0)5, Champaign, IL 618244005

109. Laura Thomas, Marketing Manager, York International Corporation, P.O. Box 1592, York, PA $17405-1592$

110. Samuel G. Tornabene, Edison Electric Institute, 1111 19th Street, N.W., Washington, DC 2(0)36-3691

111-135. R. D. Wendland, Electric Power Research Institute, 3412 Hillview Avenue, Box 10412, Palo Alto, CA 94303

136. Maurice W. Wildin, Professor, The University of New Mexico, Department of Mechanical Engineering, Albuquerque, NM 87131

137. Office of Assistant Manager for Energy Research and Development, Department of Energy, ORO, Oak Ridge, TN 37831

138-147. Given distribution as shown in DOE/OSTI-45(X)-R75 under Category UC-202 (Thermal Energy Storage) 

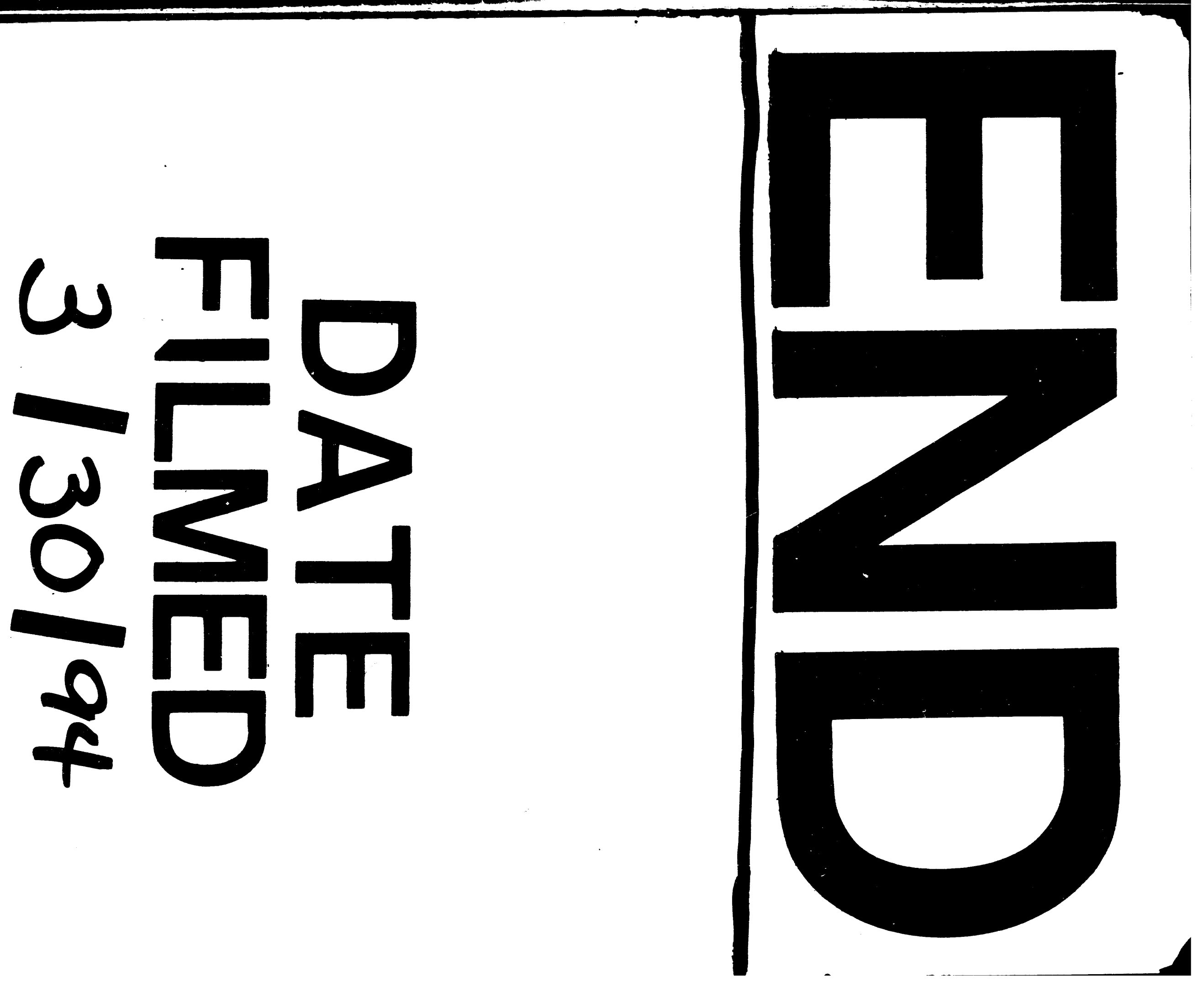
$\mid$

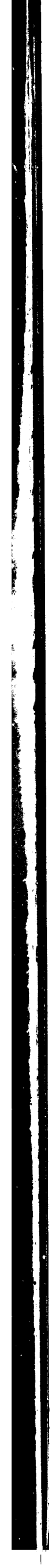
.
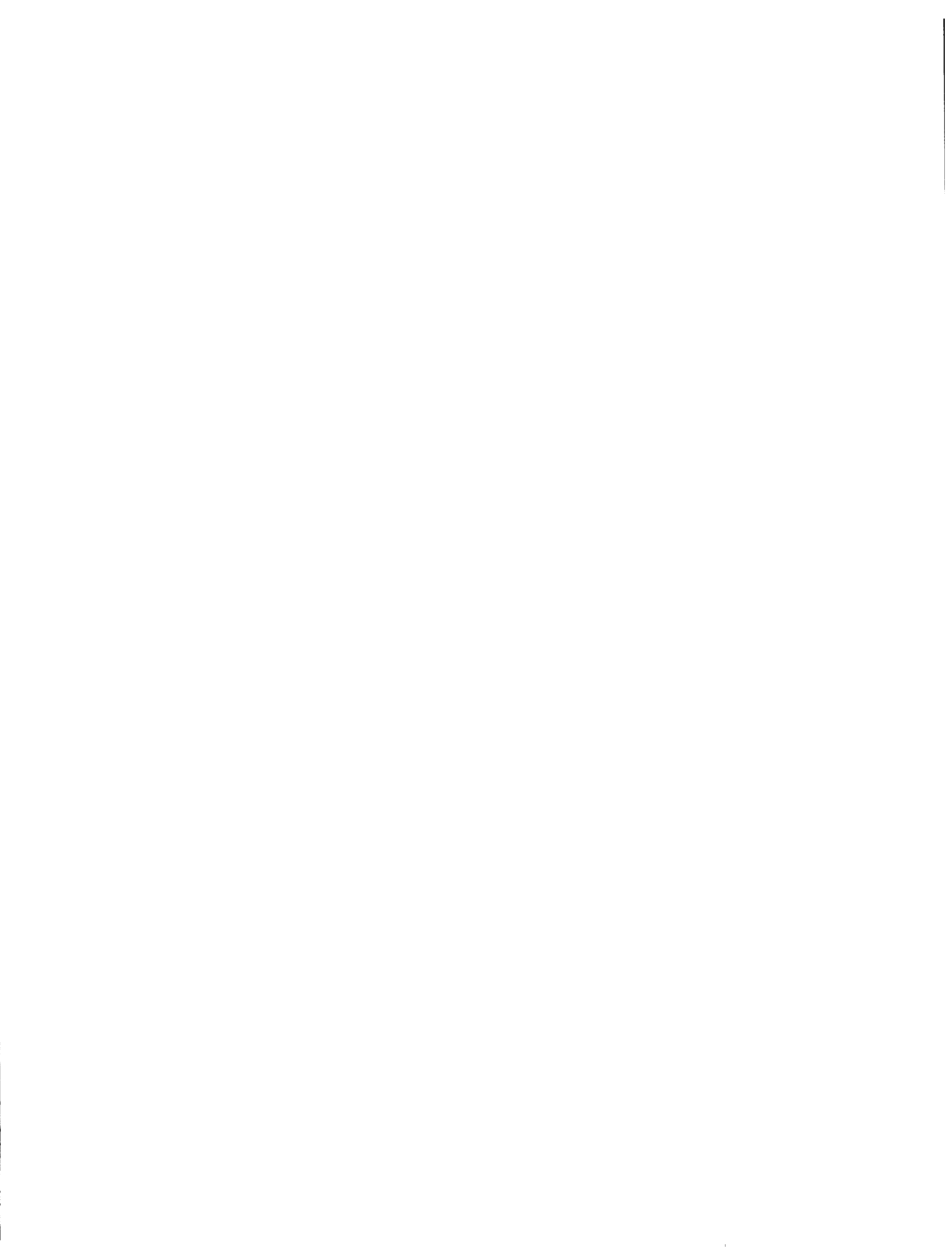